\title{
Impact of Green Roofs and Vertical Greenery Systems on Surface Runoff Quality
}

\author{
Imane Hachoumi, Bernhard Pucher (D), Elisabetta De Vito-Francesco (D), Flora Prenner (D), Thomas Ertl (D), \\ Guenter Langergraber (D), Maria Fürhacker (D) and Roza Allabashi *(D)
}

Institute of Sanitary Engineering and Water Pollution Control, University of Natural Resources and Life Sciences (BOKU), Muthgasse 18, A-1190 Vienna, Austria; hachoumi.imane@gmail.com (I.H.); bernhard.pucher@boku.ac.at (B.P.); elisabetta.de-vito-francesco@boku.ac.at (E.D.V.-F.); flora.prenner@boku.ac.at (F.P.); thomas.ertl@boku.ac.at (T.E.); guenter.langergraber@boku.ac.at (G.L.); maria.fuerhacker@boku.ac.at (M.F.)

* Correspondence: roza.allabashi@boku.ac.at; Tel.: +431-47654-81140

Citation: Hachoumi, I.; Pucher, B.; De Vito-Francesco, E.; Prenner, F.; Ertl, T.; Langergraber, G.; Fürhacker, M.; Allabashi, R. Impact of Green Roofs and Vertical Greenery Systems on Surface Runoff Quality. Water 2021, 13, 2609. https://doi.org/10.3390/ w13192609

Academic Editor: Ghassan Chebbo

Received: 9 July 2021

Accepted: 18 September 2021

Published: 22 September 2021

Publisher's Note: MDPI stays neutral with regard to jurisdictional claims in published maps and institutional affiliations.

Copyright: (c) 2021 by the authors. Licensee MDPI, Basel, Switzerland. This article is an open access article distributed under the terms and conditions of the Creative Commons Attribution (CC BY) license (https:/ / creativecommons.org/licenses/by/ $4.0 /)$.

\begin{abstract}
Green roofs (GRs) and vertical greenery systems (VGSs) can contribute certain pollutants to stormwater runoff, affecting the quality of the receiving waters. The objective of this review paper is to discuss the potential impact of these systems on the quality of urban runoff. In the green building systems section, a series of materials used in greenery systems and their specific application are presented and environmentally relevant substances that could be leached out from these materials are identified as potential pollutants. After the identification of environmentally relevant pollutants that have already been measured in urban runoff and originate from these systems, an assessment of their pathways, fate, and impact in the aquatic environment is performed. Since GRs and VGSs are already considered to be solutions for stormwater quantity and quality management in urban areas, recommendations for mitigating their environmental impact through runoff are needed. It can be concluded that special focus should be placed on measures that target the pollution source, such as optimizing GR and VGS construction practices and materials used, as well as establishing appropriate decentralized stormwater treatment measures. Both of these approaches will help to reduce or even entirely avoid the emission of relevant pollutants into the aquatic environment.
\end{abstract}

Keywords: green roof (GR); vertical greenery systems (VGSs); leaching; pollutants; runoff quality; stormwater runoff; mitigation

\section{Introduction}

The future development of urban areas is challenged by multiple pressures, such as densification of the available space, population growth, resource depletion, and the effects of climate change. Climate change in particular acts as an amplifier, increasing the temperature and causing more high-intensity rainfall events [1]. Rising temperatures and heat waves combined with sealed surfaces create urban heat islands (UHI) [2], resulting in discomfort as well as causing fatalities in the urban population [3].

One of the main mitigation strategies is the implementation of nature-based solutions (NBSs) [4]. For urban water management, the use of NBSs for decentralized water retention and infiltration is of high import and implemented through concepts such as low-impact developments and sustainable urban drainage systems [5] or the sponge city approach [6]. Due to their multifuncionality, NBSs such as green roofs (GRs), vertical greening systems (VGSs), bioretention cells, and raingardens are, besides their applications in urban water management, also effective measures for UHI mitigation [7].

With the introduction of the circular economy concept using NBSs for circular cities [8] and the definiton of urban circulartiy challenges [9], NBSs are becoming an important tool to foster sustainable urban development and resource reuse strategies. This is of utmost importance as it connects the mitigation strategies of urban water management and UHI 
and prevents resource depletion. This is especially crucial for water, as plant-based NBSs need water by design to ensure their multifunctionality [10].

Water reuse also raises the question of water quality. Several researchers have already investigated the role of specific NBSs as a pollution barrier for ground water [11-14]. For building integrated NBSs, such as GRs and VGSs, the research during the last two decades focuses mainly on improving their design and construction to foster, e.g., easy and safe building, reduced maintenance requirements, optimized irrigation, and the selection of appropriate plants. Being complex systems composed of several layers of either natural or synthetic materials and including recycled components in contact with rainwater, the legitimate question arises as to what impact GRs and VGSs may have on the quality of surface runoff in urban areas.

It is a known fact that materials used for the construction of GRs and VGSs contain different water-soluble chemicals that can be released and discharged into the aquatic environment [15-17]. As water quality improvement and reuse are important functions of NBSs, selecting proper materials is critical.

\section{Literature on Green Roofs and Vertical Greening Systems}

To illustrate the ongoing research concerning GRs and VGSs in general and research specifically investigating their potential leaching of pollutants, an ABS-TITLE-KEY search was performed on SCOPUS using the key words listed in Table 1. The keywords presented in Table 1 were used to search firstly for publications concerning GRs and VGSs in general (the first step). In the second step, additional search strings were used to look for pollutants leaching from GRs and VGSs; this is shown by "AND" at the start of the section "Focus on Pollutants".

Table 1. ABS-TITLE-KEY search for green roofs and vertical greenery systems.

\begin{tabular}{|c|c|}
\hline General & Search strings for ABS-TITLE-KEY search \\
\hline GR & (green AND roof* AND runoff*) \\
\hline VGS & (green AND wall ${ }^{*}$ OR living AND wall ${ }^{*}$ OR green AND fa?ade ${ }^{*}$ ) \\
\hline \multicolumn{2}{|c|}{ Focus on pollutants } \\
\hline GR & AND (pollutants OR biocides OR metals OR plasticizers*) \\
\hline VGS & $\begin{array}{l}\text { AND (Leach* AND quality AND runoff AND (Pollutants OR } \\
\text { chemicals OR biocides OR metals OR plasticizers*)) }\end{array}$ \\
\hline
\end{tabular}

For GRs in general, a total of 803 manuscripts were found, while 90 publications address the leaching of pollutants from GRs (Figure 1a). Based on the abstracts, only 45 of the 90 publications fit the scope of this review paper. For VGSs, a total of 363 documents were found, with 62 publications including pollutants (Figure 1b). Of the 62 publications, 26 fit the scope of this review paper. In the next step, the publications fitting our scope were searched for the terms "leaching", "contamination", and "release" and only 36, 21, and 36 publications were found, respectively. This result indicates an existing research gap concerning the knowledge about potential environmental pollutants originating from GRs and VGSs.

To close this gap, this study aims to identify the potential impacts of materials used in GRs and VGSs on surface runoff quality. This was performed by analyzing the scientific literature as well as available information from the green building sector. The authors would like to emphasize that this paper is not intended to be a comprehensive synthesis of articles that have found definite pollution in GR and VGS runoff, but instead aims to provide a deeper insight into the materials used in greenery systems and help raise awareness about their potential impacts on surface runoff quality.

The main goals of this research include:

- Providing an overview of GR and VGS systems, the materials used, and the potential pollutants associated with these materials (Section 2); 
- Assessing the impact of greenery systems on the quality of urban runoff and identifying environmentally relevant pollutants in their runoff (Section 3);

- Delineating pollutants' pathways and their environmental risk potential (Sections 4 and 5); and

- Identifying mitigation strategies for the circulation of these pollutants in urban areas (Section 6).

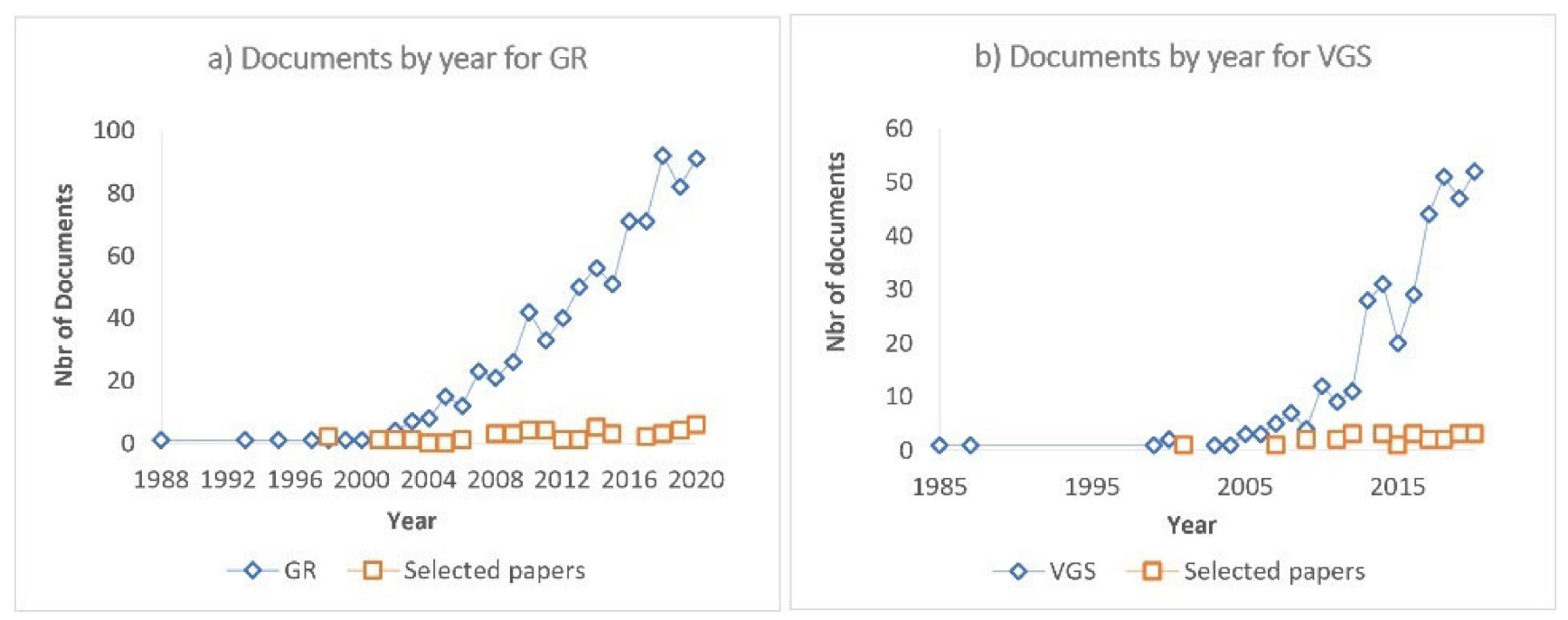

Figure 1. Publications by year of green roofs (a) and vertical greenery systems (b) compared to publications selected in our study (source; Scopus ${ }^{\circledR}$ ).

\section{Green Building Systems}

NBSs in the built environment can be categorized based on their scale of implementation into green building systems and green building sites [18]. Green building systems in particular are highly valuable to create greener cities as the horizontal space between buildings is scarce. NBSs implemented within the building envelope include VGSs, such as ground-based green facades, wall-based green facades, pot-based green facades, and vegetated pergolas as well as GRs, designed either as intensive or extensive systems $[8,19,20]$. VGSs and GRs are multifunctional systems contributing to various urban challenges. Their insulating characteristic supports reduced energy requirements for the heating and cooling of buildings. Depending on the available water supply, plant transpiration leads to a temperature reduction and therefore the mitigation of the UHI effect. GRs are used for stormwater retention, supporting the reduction of the runoff from roof tops and reducing the pressure on the static sewer system [5]. Here, VGSs only play a minor role, but can support retention when coupled with a GR. Both systems support biodiversity and act as a habitat for multiple species.

\subsection{Green Roofs}

A GR is an engineered nature-based system implemented on top of a building. Depending on their design, GRs can serve several purposes, including stormwater retention, providing insulation to the building and reducing the energy demand for cooling or heating, and mitigating the UHI effect, while creating peaceful retreats for people and animals [21]. GRs are generally categorized as either 'intensive' or 'extensive' systems. Extensive GRs have a very shallow depth of growing medium (mostly less than $15 \mathrm{~cm}$ ) and are primarily used for their environmental benefits, such as stormwater management, and insulating properties. In contrast, intensive GRs are systems with a higher depth of growing medium, which allows for a greater diversity in the size and type of vegetation. They generally require growing media depths greater than $15 \mathrm{~cm}$ and intense maintenance. Intensive GRs tend to be more expensive than extensive roofs because of the need for a more structurally 
sound building to support the weight [22]. Different vegetation types or features, such as stones, sandy soils, or dead wood added to create wildlife habitats, can result in a variety of colours and textures [23].

GRs commonly consist of several layers, namely the planted vegetation, the growing medium, a filter layer, a water drainage and storage layer, a protective and storage fleece, and a waterproof layer (Figure 2).

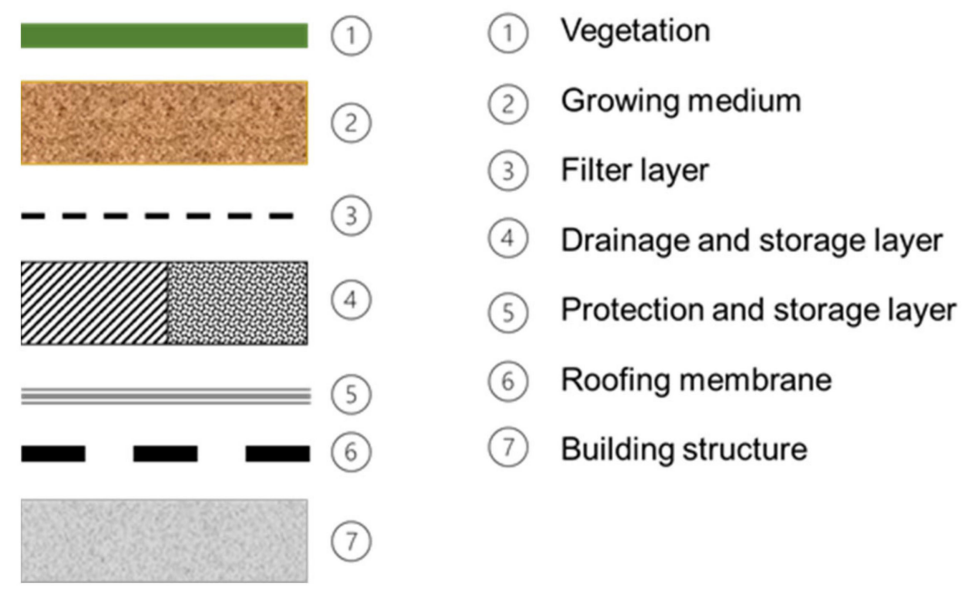

Figure 2. General structure of green roofs.

The substrate used as plant growing media (GM) typically consists of lightweight, inorganic material (e.g., sand, volcanic rocks, perlite, rockwool, expanded clay, and shale) as well as organic components, including compost, peat, or coconut coir. The substrate mixture used needs to have a high water-retention capacity, but also good drainage properties. Furthermore, fertilizers can be added to the GM to ensure sufficient nutrient supply to the plants. Below the GM, a filter layer is used to prevent fine material from moving into and clogging the drainage layer. Typically, a geotextile from polymeric fibers, such as polypropylene (PP), is used.

The drainage and water storage layer maintains the hydraulic dynamic of a GR. This layer prevents the growing media from getting saturated, while retaining sufficient water for the vegetation. The components used depend on the type of GR and include polystyrene, high-density polyethylene (HDPE), PP, stone drainage aggregates, and porous materials such as expanded clay and volcanic rocks. A protection layer made from PP or shredded rubber is used to prevent mechanical damage to the underlying waterproof layer.

For a GR, a root barrier is needed to protect the carrying structure from damage. Root barriers should not contain substances harmful to plant growth such as copper or arsenic. However, manufacturers do not always provide precise information on the inhibitors or biocides used in their products [22]. Synthetic materials such as thermosetting membranes (e.g., ethylene propylene diene monomer (EPDM)), thermoplastic membranes (e.g., polyvinyl chloride (PVC), and thermoplastic polyolefin (TPO) are root-resistant and can be used as a waterproofing membrane [22]. The most effective primary root barriers are polyethylene sheets applied directly over the waterproofing membrane, but this can reduce permeability and lead to drainage problems [22].

\subsection{Vertical Greenery Systems (VGSs)}

VGSs are NBSs implemented at the facade of a building. Several different systems are available and described using different nomenclatures throughout the scientific literature. The nomenclature used here is based on Castellar et al. [19] and the classification of NBSs by the COST Action CA17133 "Circular City" [20]. Generally, three main types exist, namely ground-based green facades, wall-based green facades, and pot-based green facades (Figure 3). 
A ground-based green facade consists of climbing plants growing vertically either directly attached to the wall or using support elements mounted on the wall. GM of ground-based green facades usually consist of soil, but a substrate mixture can also be used. Structural elements such as climbing aids are used for indirect ground-based green facades to provide support for climbing plants. These guides include wires, cables, trellises, and meshes made of materials such as stainless steel or galvanized steel [24,25], wood, or plastic-based materials.

Wall-based systems use panels filled with GM fixed to the facade or free-standing structures. The vegetation covers the whole vertical area of the panel. GM of wall-based systems consist of a substrate mixture or alternative growing media such as rockwool. Substrate mixtures include organic material such as soil, cork, coconut fibers, and peat moss [26,27]. Alternatively, lightweight screens made of geotextiles are used as GM and act as support elements at the same time. However, these soil-less systems need a constant supply of water and additional nutrient input [24]. The support element of wall-based systems contains GM and vegetation. Often, geotextiles are used, consisting of plasticbased materials such as PP, polyamide, PE, PET, polycarbonate, and LDPE [25-28] or organic material such as viscose [26]. The structural element of a wall-based system holds the support element and connects it to the facade. The materials used comprise metal-based materials such as aluminium and steel S235 [25-27] and plastic-based materials such as HDPE [28]. The irrigation system consists of pipes made of plastic-based materials such as polyethylene $[25,26]$.

A pot-based green facade consists of individual or connected containers placed either on the ground or mounted on the facade. A broad variety of plant species can be used. Depending on the size of the pot, it is either directly filled with GM or constructed using similar layers as described for GRs. This type of VGS is also used for greywater treatment to support water reuse at the building scale $[29,30]$. Plants in pot-based facades grow in a variety of GM such as soil, alternative GM, or a mixed substrate. Mostly lightweight materials with a high water-retention capacity are chosen. Materials used include amongst others potting soil, expanded clay, coconut fibers, humus, peat, and sand [24,26]. Additionally, fertilizing products can be added to ensure a good supply of nutrients to the plants $[24,26]$. Support elements of pot-based systems can have different sizes, ranging from single pots or bags to bigger-sized planter boxes. These elements are made of either plastic-based materials (such as PE and PP) or metal-based materials (such as aluminium, galvanized steel, and stainless steel) $[24,25,27]$. Structural elements ensure that the support elements of pot-based green facades are held in place. Materials include stainless steel, steel S235, galvanized iron, and aluminium $[25,26]$. For the irrigation system, mainly PE pipes are used.

Table 2 represents a summary of materials used for the construction of the described greenery systems, their specific application (which element of the GR and VGS), and the chemical substances known to be used in their production or application. These chemical ingredients are considered to be potential pollutants, as they can be emitted from GRs and VGSs under atmospheric exposure. It has to be mentioned that this information (Table 2; column "potential pollutants") is partly derived from the scientific literature, as the information provided by material producers is very scarce. For some materials, no information could be found regarding potential pollutants, so that the column "potential pollutants" could not be completed. 
Table 2. Materials used in green roofs and vertical greenery systems and potential pollutants.

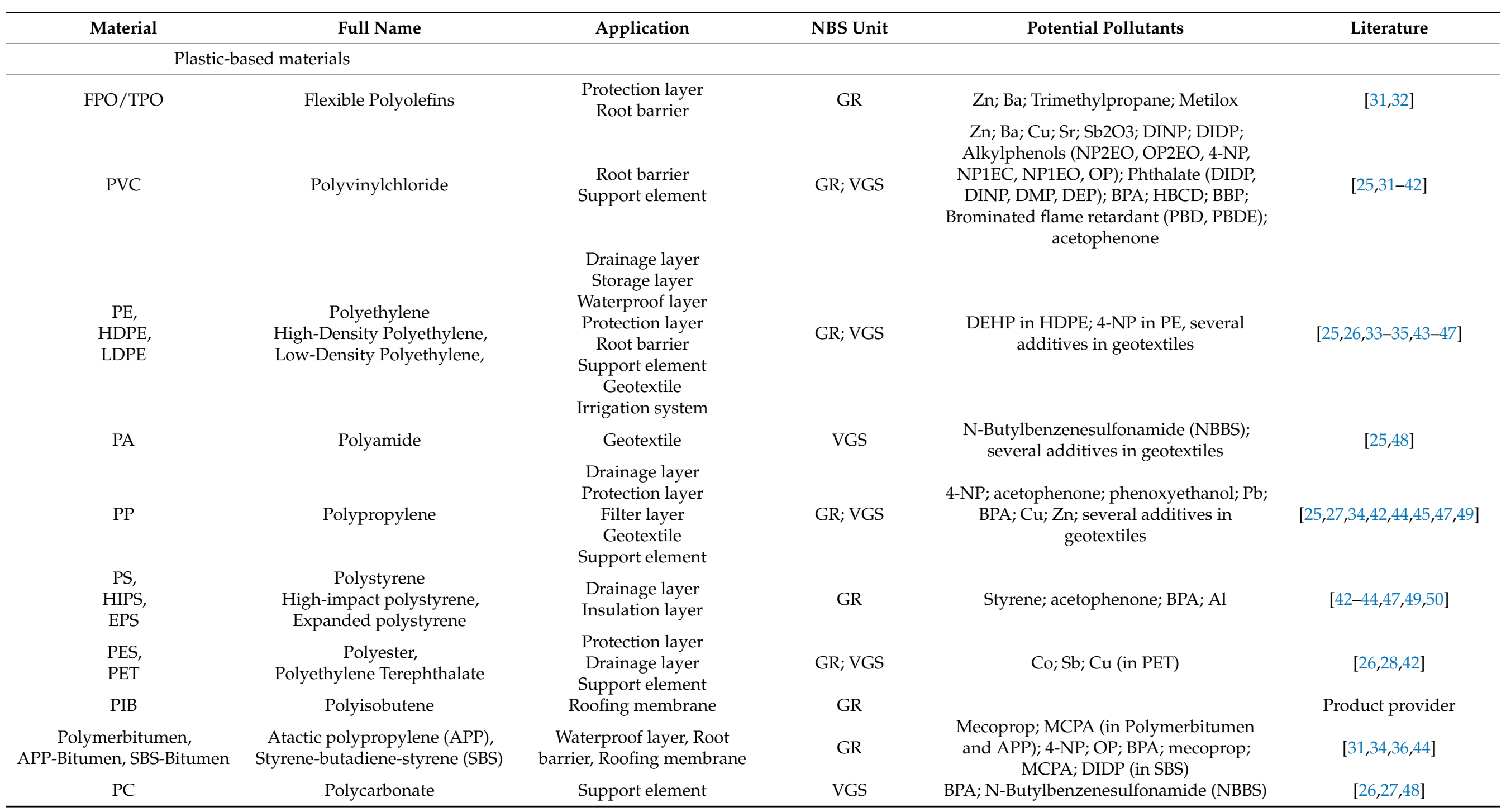


Table 2. Cont.

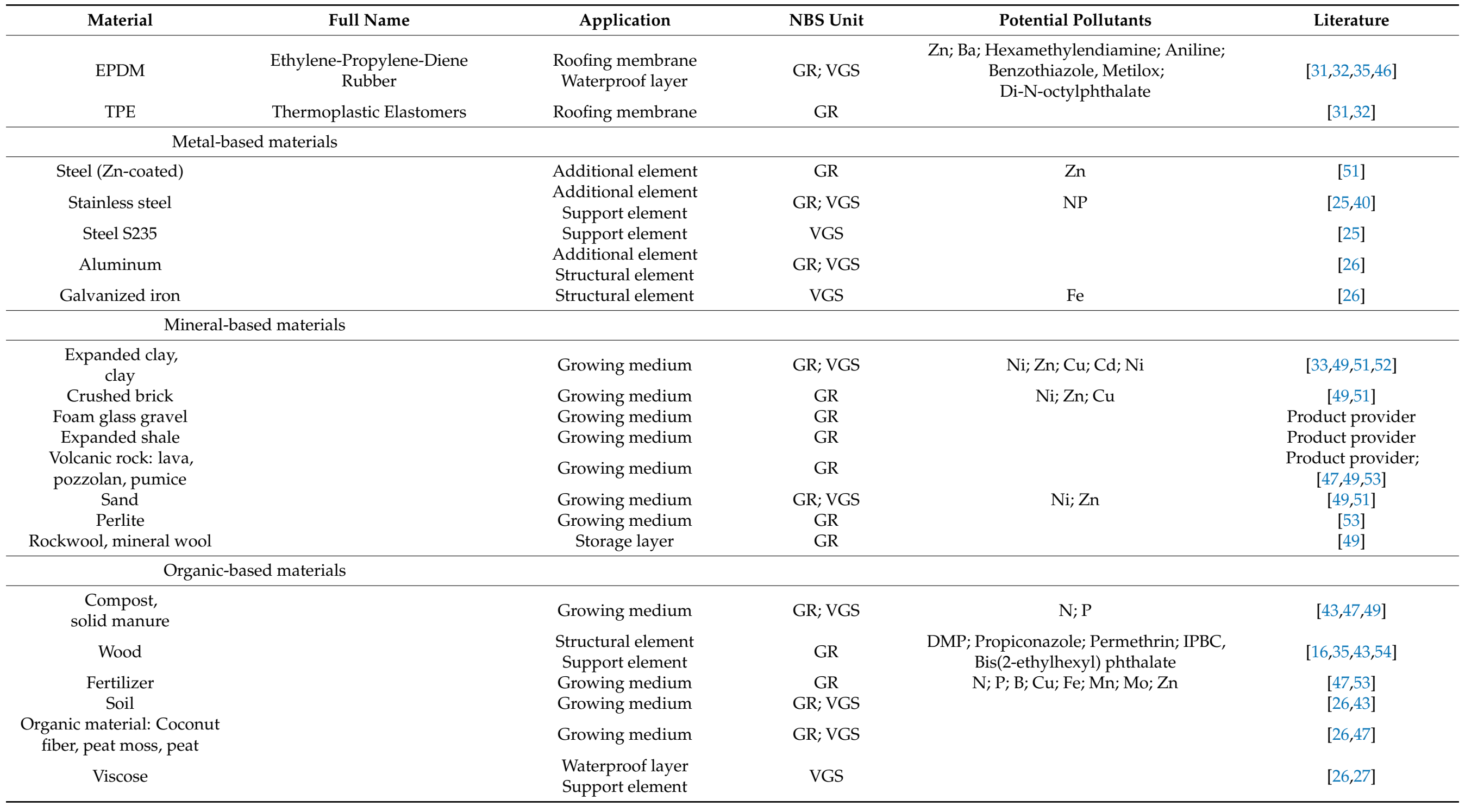



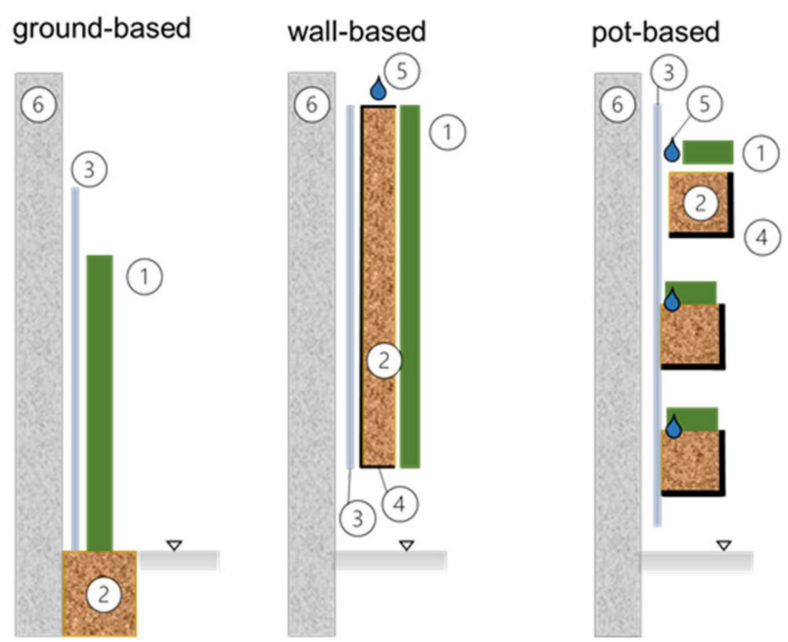

(1) Vegetation

(2) Growing medium

(3) Structural element

(4) Support element

5) Irrigation system

(6) Building structure

Figure 3. General structure of vertical greenery systems.

\section{Green Buildings and Runoff Quality}

A variety of micropollutants detected in surface waters have been identified as originating from materials used in buildings, including GRs and VGSs [31,52,55-59]. Roofs have been determined as the surfaces generating more than $50 \%$ of the total volume of runoff water and as one of the main non-point sources of pollutants in urban areas [60]. In recent years, studies conducted on roof runoff have shown that these are characterized by high concentrations of metals due to leaching and corrosion of roofing materials, especially under the effect of acidic rain [60].

Since GRs are a measure for stormwater management in urban areas, many studies have been published that deal with the question of whether they act as sinks or sources for environmental pollutants $[17,52,61]$. GRs are considered a source of contaminants if the contaminant concentration in the GR runoff leachate is higher than that in the rainwater or runoff from a bare roof. Otherwise, GRs are considered a sink for these contaminants [62]. In contrast to conventional roofs, GRs have the potential to behave as a pollution sink, reducing the concentration of targeted substances in the input water (e.g., precipitation), due to retention in the substrate or vegetation [55].

Being complex constructions, GRs exhibit the potential to act as pollution sources for certain environmentally relevant substances present in the used materials, as summarized in Table 2. The first point of concern is the wide application of plastic materials, which is justified by GR experts as a way to reduce the overall weight and improve the performance of waterproofing layers without compromising the benefits of GRs [45]. These materials can be pollution sources for substances used in their production and known to be of environmental concern, such as plasticizers or flame retardants. The other point of concern is the general effort of using materials with the potential for reuse and recycling to support the shift towards a circular economy. The use of these waste-based materials, recycled materials, or reused materials in green buildings can have a negative impact on runoff quality because of the re-emission potential for certain pollutants adsorbed on their surfaces [32].

Similar considerations apply to VGSs. Wall-based and pot-based VGSs are constructed using a combination of metal or plastic and a synthetic fabric to support the establishment of a diverse and dense plant community. Each of the elements and materials used could contribute to the leaching of organic chemicals with harmful effects on health due to a reduction in runoff water quality. 
According to the literature consulted for this study, the following groups of environmentally relevant substances were identified as emission sources from GRs and VGSs into the aquatic environment:

- Metals, which are released from metallic building constructions (mostly aluminium and steel);

- Additives, which represent chemicals used for a certain purpose in GRs and/or VGSs. These can be substances applied during the construction of the green element for various purposes (biocides, herbicides, and flame retardants) and others used to improve certain properties of construction materials (plasticizers, vulcanization accelerators, etc.); and

- Nutrients, which are mainly used as fertilizers in GRs and VGSs.

Therefore, the following discussion focuses on these groups of substances, aiming to give an overview of the existing literature on their concentrations in the aquatic environment and the relevant sources of release.

\subsection{Metals}

Metallic materials are widely used in urban areas for various construction purposes. These, as well as concrete and asphalt products, have the potential to release metals into urban stormwater runoff. Research on this topic has been widely documented and several studies have already confirmed severe metal contamination in runoff from metallic or partly metallic roofs and facades $[35,63,64]$.

One study compared various roofing materials with different runoff pollution potentials and showed that aluminium and stainless steel panels and gutters had lower metal emission levels, reflecting the good corrosion resistance of these materials [65]. The authors concluded that older materials release a higher number of metallic species with higher levels of emission. This may be due to the fact that lead used in roofing mainly originates from recycled material and that purification steps are not sufficient to eliminate all species present in initial alloys [65]. According to Clark et al. [66], the emission of metal from aged roofing panels can be observed even after 60 years of operation. A recent study by McIntyre et al. [67] investigated emissions of three metals ( $\mathrm{As}, \mathrm{Cu}$, and $\mathrm{Zn}$ ) from experimental panels of 14 different roofing materials over 4.5 years of in situ weathering. These were copper, mainly from treated wood shake panels, followed by copper granule-containing asphalt shingles. In addition, arsenic was estimated to be emitted from wood shake panels too, with copper-chromated arsenic. Zinc was believed to originate from commercial roofs, including Zincalume ${ }^{\circledR}$ and painted metal roofs. This indicates that roofing materials can be an important long-term source of $\mathrm{As}, \mathrm{Cu}$, and $\mathrm{Zn}$ in stormwater runoff. This result correlates with [68]. In the same study, [67] observed a much lower release of $\mathrm{Zn}$ from painted galvanized steel than from Zincalume ${ }^{\circledR}$, which demonstrates the importance of coating for reducing metal emissions from metal roofing materials. This has been confirmed by Clark et al. [66] and Robert-Sainte et al. [65].

The study by Berndtsson et al. [61] investigated the runoff water quality from four extensive GRs located in different study areas in southern Sweden with regard to their behavior in heavy metal pollution. Runoff and rainwater samples were analyzed for cadmium $(\mathrm{Cd})$, chromium $(\mathrm{Cr})$, copper $(\mathrm{Cu})$, iron $(\mathrm{Fe})$, potassium $(\mathrm{K})$, manganese $(\mathrm{Mn})$, lead $(\mathrm{Pb})$, and zinc $(\mathrm{Zn})$. Results show that these roofs act as a source of contaminants. This is due to the fact that rainwater in the studied areas during the study period was relatively uncontaminated, and the retention time in the extensive vegetated roofs was relatively low, limiting any substantial influence of the roofs on water quality. The concentration of copper in the runoff from the GR at one of the study sites was significantly higher, which was attributed to the rain pipes made of copper and not the vegetated roof material [61]. Contrary to this, Alsup et al. [15] and Vijayaraghavan et al. [69] found that GRs have the potential to act as sinks for various metals rather than sources. The results from these studies indicate that the substrates used in the simulated GR systems contribute to metal removal from the wet depositions $[15,69]$. 
Another study by Alsup et al. [52], in Edwardsville (Illinois, United States), investigated the leaching of metals $(\mathrm{Cd}, \mathrm{Fe}, \mathrm{Ni}, \mathrm{Pb}$, and $\mathrm{Zn})$ from a simulated GR called the "built-in-place" (BIP), which had been subjected to 22 months of exposure to natural conditions. This system consisted of a wood frame, galvalume-treated sheet metal edging, a drainage layer and root barrier, and an ethylene propylene diene terpolymer (EPDM) roofing membrane adhered to a wafer board substrate. The substrate was reported to have been a mixture of fine Arkalyte and composted pine bark [52]. Arkalyte is an expanded clay and a proprietary substrate that is used in GRs. The objective of the study was to determine whether the leaching of metals originated from the components of the BIP systems or the Arkalyte mixed with pine bark used as a substrate, whether it is attributable to the substrate's depth, or whether it is introduced through wet/dry deposition [52]. The study revealed a leaching of $\mathrm{Cd}, \mathrm{Pb}$, and $\mathrm{Zn}$ at all four sampling dates at concentrations exceeding water quality criteria [70], while the leaching of $\mathrm{Ni}$ exceeded the criterion for chronic toxicity at one sampling date. The data demonstrate that the substrate was the source of metal emissions (particularly $\mathrm{Cd}, \mathrm{Fe}$, and $\mathrm{Pb}$ and perhaps $\mathrm{Ni}$ ), confirming that components of the system contributed to metal leaching. These results are in accordance with the previous study of the same authors [17], where they showed that the same green roof substrate had the potential to leach heavy metals, particularly $\mathrm{Cd}$ and $\mathrm{Pb}$. Other authors [61] have confirmed that this mixture displays "first flush" effects, releasing exchangeable metals upon the first wetting. Further studies have reported that green roof substrates act as sinks for Zn [55]. It can be concluded that different aspects of GR construction can influence leachate quantity and quality, both through the chemical composition of the substrate and its depth [52].

Speak et al. [56] compared an established (GR) and a conventional roof surface (bare roof) and found high concentrations of some heavy metals for both roofs; $\mathrm{Cu}, \mathrm{Pb}$, and $\mathrm{Zn}$ levels exceeded the environmental quality standards (EQS) for the protection of surface water quality under directive 2013/60/EC [71]. Lead levels were found to be elevated during rainfall, both for the GR and the bare roof, suggesting that the origin of $\mathrm{Pb}$ is likely historic urban atmospheric deposition. The study also highlighted the need to consider local atmospheric pollution inputs when installing a GR. Because GRs tend to capture air pollution, the pollution may accumulate and cause problems with reduced runoff water quality in the future [56].

Based on a recent study by Karczmarczyk et al. [51], a list of 29 GR substrate components were tested regarding their potential for leaching of contaminants to urban receivers. Out of the materials tested, those of natural origin, including sands and gravels, showed a very high release of $\mathrm{Ni}$ and $\mathrm{Zn}$ into runoff. In the group of human-made materials, crushed red brick, expanded clay, and ash were strongly polluted with $\mathrm{Ni}, \mathrm{Zn}$, and $\mathrm{Cu}$. Regarding $\mathrm{Ni}$ emissions, four of the tested mineral materials were characterized as materials associated with high risks in application [51].

To the best of the authors' knowledge, there is very little research (two studies) investigating the impact of VGSs on metal emissions into surface runoff, as shown in Figure 1. One possible reason for this is that VGSs are a more recent design feature compared with GRs, and new types of systems are still being studied, tested, and produced (e.g., climbing plants, hydroponic walls, vertical green wall panels, vegetation on plant containers along the facades, etc.) [72]. According to the literature on these systems, metal emissions are to be expected, as the systems are mostly constructed using metal frames (aluminium, galvanized steel, or stainless steel) [73]. 


\subsection{Additives}

Biocides are widely used as preservatives in coatings to protect the material against algae, fungi, and bacteria. Other additives such as flame retardants and herbicides are used to protect the construction elements against fire or damage through root penetration. Furthermore, numerous additives are used in the production of materials used for construction to improve their properties, such as plasticizers, vulcanization accelerators, and UV filters.

Some of the mentioned substances have already been detected in surface runoff, confirming their leaching potential under certain atmospheric conditions. A large number of studies have shown that biocides, herbicides, and other additives can leach out from construction materials during rain events, underlining the role of urban sources in the diffuse pollution of aquatic systems [54,74-78].

\subsubsection{Biocides/Herbicides}

Biocides and biocidal products are chemical substances that are used to "destroy, deter, render harmless, prevent the action of, or otherwise exert a controlling effect on any harmful organism by chemical or biological means" [79]. Biocidal active substances are often used in renders and paints for exterior facade coatings and roofing material to avoid the growth of fungi and algae on the surfaces of buildings [78]. Biocides counteract microorganisms by migrating from the deeper layer to the surface of the coating and are hence washed off by incoming rain and incorporated into the runoff [80].

Burkhardt et al. [54] investigated the release of three biocides, terbutryn, carbendazim, and cybutryne (Irgarol 1051), and the herbicide mecoprop from building materials and found that their concentration after the first flush of stormwater runoff exceeded the Swiss water quality standard of $0.1 \mu \mathrm{g} / \mathrm{L}$ for each investigated substance. They demonstrated that the leaching rate of mecoprop depends on material characteristics such as surface modification, thickness, concentration of the root barrier agent, and its chemical structure [54].

Benzalkonium chloride is another biocide used in roof maintenance to fight against moss, lichens, and algae. Gromaire et al. [36] studied the evolution of roof runoff contamination by benzalkonium chloride over a one-year period, and the results show a major contamination of roof runoff immediately after the use of the substance followed by an exponential decrease [36].

Recent studies have focused on the emission of biocides by facades in connection with the application of paints or plasters containing one or more biocidal compounds in their formulation $[16,76,78,81]$. The emission of other biocides, such as diuron and isothiazolinone, but also terbutryn and carbendazim, has been studied by $[75,77,81]$.

One of the most frequently investigated pollutants known to be contained in construction material and for having a strong negative impact on runoff quality is the herbicide mecoprop. It is permitted for use on ornamental lawns, recreational turf, sports fields, sod farms, roadsides, industrial areas, and right-of-ways. Mecoprop is a commonly known root barrier agent and is widely used in bitumen layers in flat roofs and GRs to protect the building structure from root penetration. The annual use of the root barrier agent mecoprop used in bitumen sheets for water proofing reached between 40 and $50 \mathrm{t}$ in Switzerland [54].

Investigations at the Swiss Federal Institute for Water Resource and Conservation on behalf of the Federal Materials Testing and Research Institute showed that, under natural weather exposure, mecoprop is released from the bitumen layers and emitted to the aquatic environment [82]. Many other studies have confirmed the release of mecoprop from root-resistant bitumen roofing membranes and reported raised concentrations in urban runoffs [82-84]. Gerecke et al. [85] observed high concentrations of mecoprop in the effluents of wastewater treatment plants during rainy days and confirmed its origin to be bitumen roof terraces because, at that time, racemate (a 1:1 ratio between the two enantiomers (R)- and (S)-mecoprop) was used in roof materials, while only the R-enantiomer was applied in agriculture. 


\subsubsection{Plasticizers}

The use of plastic in GRs is justified by green roof experts as a way of reducing the overall weight of the system, while improving the performance of waterproofing layers, without compromising the benefits of GRs [45]. It is a known fact that plastic materials contain plasticizers as additives to improve the properties of the material. Plasticizers, such as phthalate esters (PAEs), alkylphenols (APs), and relative phenols, are human-made chemicals mainly used to improve the flexibility or processability of materials such as plastic [38,39].

Gromaire et al. [34] performed an experimental methanol leaching test on materials commonly used in extensive GR structures in order to identify the presence of alkyl phenolic compounds (APs) and bisphenol A (BPA) [34]. They reported that APs and BPA were detected in most materials at different leached levels. Styrene-butadiene-styrene (SBS) polymeric bitumen membranes leached BPA between 14 and $23 \mathrm{ng} / \mathrm{g}$, and very high nonylphenol (NP) leaching (400 to $2400 \mathrm{ng} / \mathrm{g}$ ) and lower octylphenol (OP) leaching (between 3 and $13 \mathrm{ng} / \mathrm{g}$ ) were found [34]. PVC gutters showed significant leaching of BPA (9 to $70 \mathrm{ng} / \mathrm{g}$ ) and lower quantities of NP leaching (1 to $11 \mathrm{ng} / \mathrm{g}$ ) and nonylphenol acetic acid leaching ( 1 to $6 \mathrm{ng} / \mathrm{g}$ ). These results are in accordance with the information reported by [86].

The same authors performed rainfall leaching tests for these roof materials and reported that the leaching level of some APs and BPA is higher compared with the methanol leaching test. For SBS membranes, the concentrations were $64 \mathrm{ng} / \mathrm{L}$ and $26 \mathrm{ng} / \mathrm{L}$ for BPA and OP, respectively, while for PVC gutters the concentration was $34 \mathrm{ng} / \mathrm{L}$ for BPA [34]. It can be concluded that APs and BPA are released at relatively high concentrations by various materials used in the GR structure [34].

A recent study by Müller et al. [40] assessed the release of nonylphenols and phthalate compounds from different building surface materials used in GRs, green facades, or other surfaces into rainwater runoff. The materials were tested in the outdoor environment under varying weather conditions. High concentrations of nonylphenols (NPs) and di-isononyl phthalate (DINP) were found to be released from two types of PVC roofing (PVCA and PVCB). Indeed, these two types of PVC materials released high concentrations of DINP, with an average of 365 and $455 \mu \mathrm{g} / \mathrm{L}$, respectively, and average concentrations of NPs in runoff from PVCB of up to $26 \mu \mathrm{g} / \mathrm{L}$. Meanwhile, corten weathering steel displayed lower release levels. The authors also reported that NP concentrations were significantly higher in building runoff compared with bulk atmospheric deposition, which means that NPs were likely derived from building structures. Additionally, the release of these substances into the natural environment seemed to increase with rising temperatures [40].

Lamprea et al. [86] also addressed this issue, and reported high concentrations of NPs ( 1 to $10 \mathrm{ng} / \mathrm{g}$ ) leaching from PVC materials. The emission sources of phthalates in urban stormwater have been identified by [87] using substance flow analysis for quantifying the substance fluxes from the source to the stormwater system. The authors showed that roofing and facade materials represent important sources of phthalates and concluded that there was a significant lack of knowledge concerning the emission behaviour of these substances in the outdoor environment. Other authors [88] studied alkylphenols (APs) in atmospheric deposition as well as runoff within a small suburban area near Paris (France) and identified building runoff emissions as being the dominant source of alkylphenols in stormwater. 
From the consulted literature, it emerged that VGSs have so far been poorly investigated regarding their role in the emission of plasticizers in surface runoff from urban areas. Acknowledging the fact that these systems contain almost the exact same plastic materials used in GR construction (shown in Table 2), a similar behavior regarding pollution emission can be expected. Specific studies on the emission of these substances from VGSs, or experimental and numerical investigations at an urban scale, could not be found. Future research is needed for the investigation of materials used in VGSs and their leaching potential for relevant substances, including plasticizers.

\subsubsection{Flame Retardants}

The safety of GRs and VGSs, in terms of their fire hazard potential, is poorly studied. It is still debated whether, and to what extent, the presence of such roofs poses a threat to the building in this respect. Essentially these systems consist, in part, of organic components (plants and substrates), which are alleged to present an additional fuel load in the case of a fire [89]. Therefore, many of the waterproofing layers for the proper installation of GRs require the addition of flame-retardant materials, which are especially helpful in protecting the building from fire [72].

Flame retardants are chemicals used to improve the fire behavior of combustible materials. They reduce the risk of a fire starting in the case of contact with a small heat source [37]. The main types of flame retardants are compounds containing halogens (bromine and chlorine), phosphorus, nitrogen, minerals (based on aluminium and magnesium), and other types such as borax, antimony oxide $\left(\mathrm{Sb}_{2} \mathrm{O}_{3}\right)$, or chloroparaffins [90]. Chlorinated paraffins (CPs) represent $7.4 \%$ of the market; they are used in PVC as a flame retardant applied in waterproofing with PVC synthetic membranes. Brominated flame retardants (BFRs) are also present in bituminous waterproofing coatings for GRs [41,91,92]. The main brominated flame retardants are polybrominated diphenyls (PBDs), polybrominated diphenyl ethers (PBDEs), tetrabromobisphenol A (TBBPA), and hexabromocyclododecane (HBCD). According to EFRA, phosphorus-containing flame retardants (PFRs) are mainly used as plasticizers in PVC [37].

Winters et al. [35] investigated the presence of phthalates and PBDEs in runoff from different roofing materials. They reported that the treated wood shake roof was the only roof type to exhibit phthalate leaching. Bis(2-ethylhexyl) phthalate was detected for each of the three rain events investigated. Concerning the PBD congeners, PBDE-099 was detected most frequently, and congener PBDE-184 was detected least often. PBDE-153 was not detected in any rain event in runoff from any roof type [35].

\subsection{Nutrients}

Elevated nutrient concentrations in stormwater runoff could lead to challenging environmental problems, such as eutrophication in urban streams [93]. Nitrogen and phosphorus are known as the main factors influencing eutrophication because they support the growth of algae and aquatic plants.

Several researchers have investigated the nutrient emission potential of a typical GR. The substrate, including component materials, may contain nutrients $(\mathrm{C}, \mathrm{N}$, and $\mathrm{P})$ to promote plant growth, which can consequently be emitted into the environment $[59,93]$. The concentration of nitrogen in GR runoff depends on the kind of soil, the fertilizers used, and the age of the GR [57]. The substrate that is most used in GRs and VGSs is an engineered soil designed to provide structure and nutrition to support a healthy, thriving plant community. Therefore, substrates have typically not been designed with runoff water quality in mind, are typically nutrient-rich (often containing compost, which tends to be enriched in $\mathrm{P}$ ), and may be supplemented with slow-release inorganic fertilizers containing $\mathrm{N}, \mathrm{P}$, and K [94]. 
Some researchers have found that the loads of different forms of nitrogen are much lower in GR runoff than they are in precipitation [95], while others have indicated that there are significant releases of nitrogen from GRs [96]. In addition, the concentration of nitrogen in the runoff can be influenced by the configurations of the different types of GRs and their maintenance [58]. A study on GR types by Berndtsson et al. [55] investigated the influence of the vegetated roof elements (materials and substances) on runoff water quality from two GRs (an intensive GR from Japan and an extensive GR from Sweden). Results show that extensive and intensive GRs behave as sinks for nitrate nitrogen $\left(\mathrm{NO}_{3}-\mathrm{N}\right)$ and ammonium nitrogen $\left(\mathrm{NH}_{4}-\mathrm{N}\right)$ [55]. The intensive GR was also found to be a sink for total nitrogen in contrast to the extensive roof, which might be due to the fact that intensive vegetated roofs support larger plants, which means that the inorganic nitrogen taken up by plants changes to organically bound nitrogen and remains within the vegetation [55]. Aitkenhead-Peterson et al. [95] also reported a significant increase in the concentration of nitrate nitrogen (up to $2.1 \mathrm{mg} / \mathrm{L}$ ) in the runoff from GRs compared with precipitation $(0.2 \mathrm{mg} / \mathrm{L})$ [95].

Urban runoff from GRs and VGSs may also contain substantial amounts of phosphorus due to the use of artificial fertilizers. According to a study by Berndtsson et al. [61], all phosphorus in the runoff from a GR is released as phosphates, and the runoff from some GRs contained no phosphorus at all [61]. In another study, the same authors [55] observed the release of phosphorus from an extensive vegetated roof, but not from an intensive vegetated roof, which probably originated from the fertilizer and soil.

Due to a lack of information concerning the leaching of nutrients from VGSs, it can be concluded that these systems could also release some nutrients and can have a negative impact on surface water quality. Further research and awareness regarding this topic may strongly support provider and user decisions regarding the selection of the vegetated system (plant and substrate) and the fertilizer usage.

The pollutants potentially emitted from GRs and VGSs into the aquatic environment are summarized in Table 3. Additionally, the physical-chemical properties of these substances are shown in this table in order to support the discussion in the following sections regarding their distribution pathways and environmental fate. 
Table 3. Pollutants emitted from green roofs and vertical greenery systems and their physical-chemical properties.

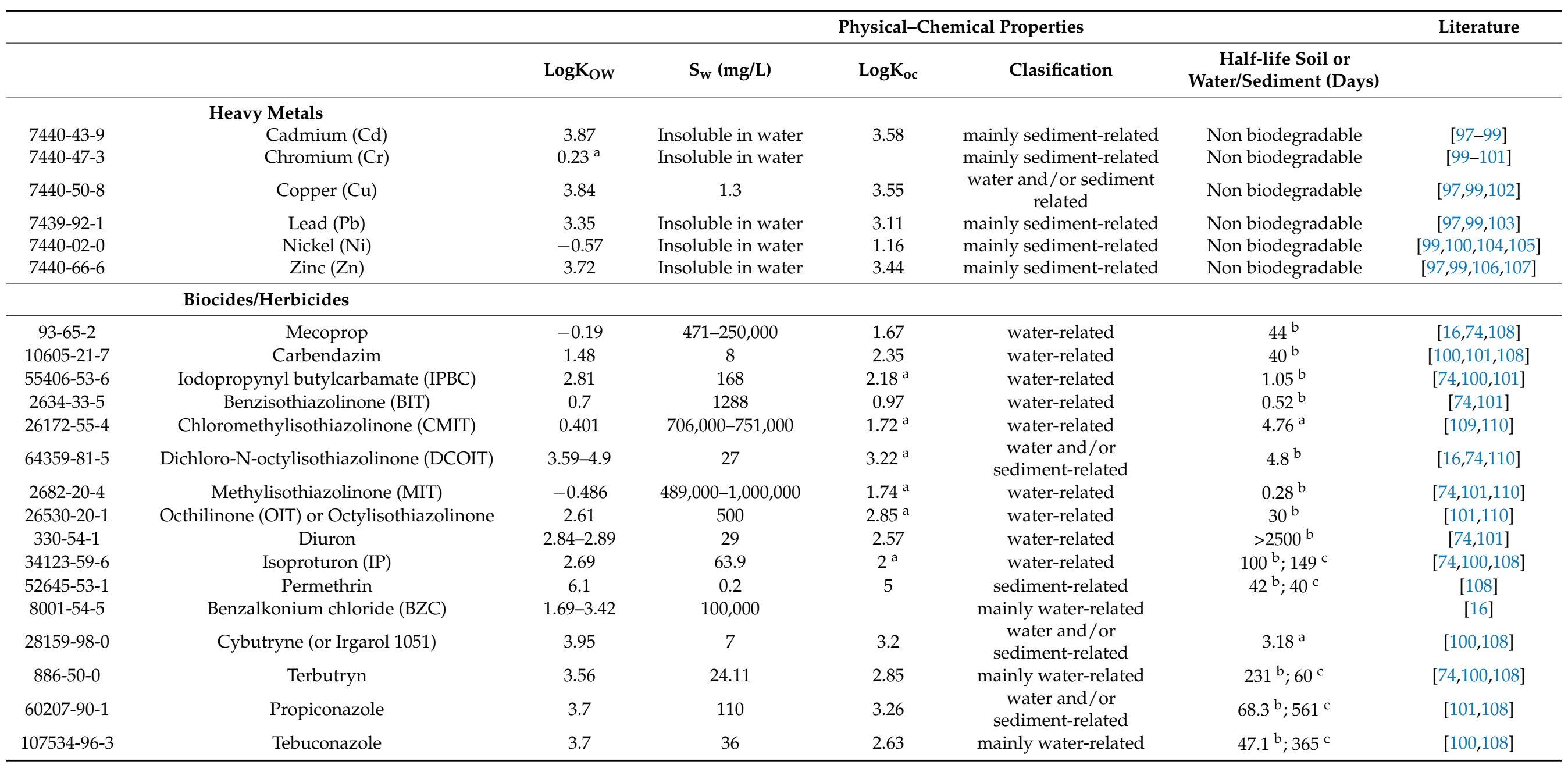


Table 3. Cont.

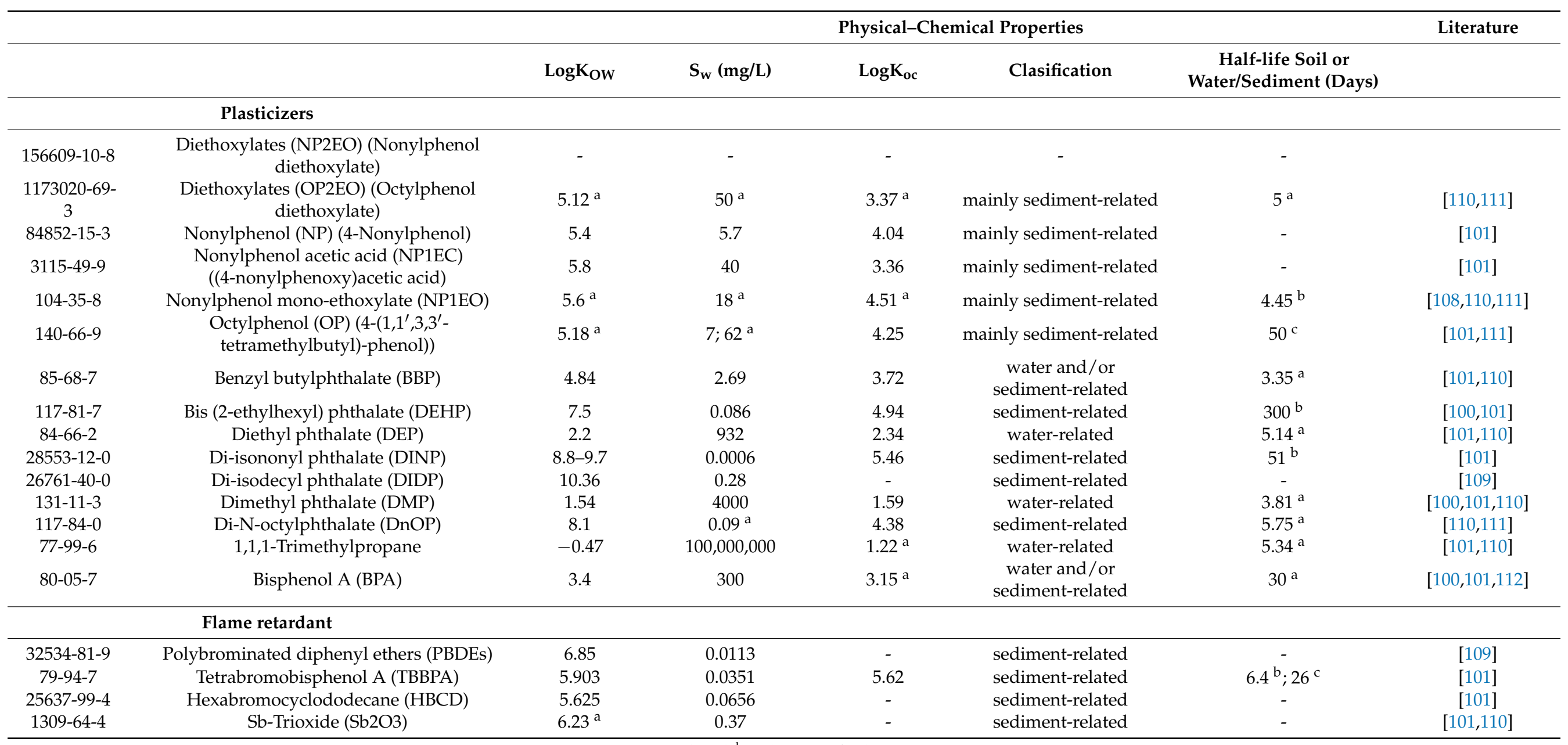

${ }^{\text {a }}$ Predicted, ${ }^{\mathrm{b}}$ Soil, ${ }^{\mathrm{c}}$ Water/sediment. 


\section{Pollutants' Environmental Fate}

The fate of the pollutants listed in Table 3 and their concentrations and spatial distribution in the environment are influenced by a combination of numerous different factors, such as the type of surface and the type of used material (soil, painting, coating, etc.), the characteristics of the precipitation and its seasonal variation, the end-of-pipe collection together with treatment facilities, and the physical-chemical properties of the compound [113-117]. Precipitation can be considered a crucial factor for the release of target compounds from green infrastructure into the aquatic environment. The compounds that accumulate on or are applied to the infrastructures' surfaces (e.g., rooftops) during dry weather can then be washed out during rain events $[16,113]$. Some studies have already indicated that the fate of pesticides from green infrastructure is influenced by the storm event characteristics, but also their use pattern and the substances' properties [74,113,118-120]. The rainfall intensity significantly affects the pesticides' concentrations in stormwater runoff; a high rainfall intensity leads to high amounts of biocides in runoff [113]. Bollman et al. [75] noted that pesticide emissions from buildings are higher during wet weather and during intense rain events (e.g., up to $116 \mathrm{mg} / \mathrm{h}$ carbendazim and $73 \mathrm{mg} / \mathrm{h}$ mecoprop).

The pollutants emitted can then enter the urban sewage system and finally end up in receiving water bodies (with or without treatment), or can be directly discharged into the soil through infiltration, reaching groundwater [113,121-124]. The pollutants' fate may be influenced by the type of sewage network system, which may be either combined or separate. In the case of combined sewer systems, the hazard of pollutants being discharged directly into the surface water might be reduced for weak storm events and if the first flush of the event itself contains the majority of pollutants, whereby most of it is transported to the wastewater treatment plant (WWTP) for further treatment. Nevertheless, in the case of a strong storm event and if the pollutant concentration remains rather constant throughout the event, combined sewer overflows (CSO) are considered a significant source of pollutants for the receiving water bodies. However, according to Zgheib et al. [124], long in-sewer residence times in combined systems induce more chemical and microbial processes, which is not the case in stormwater sewers. This enhances the likelihood of discharge of untreated pollutants into receiving waters in the case of separate systems [124]. As a matter of fact, urban stormwater runoff is considered an important source of pollution for receiving waters, and substances leaching from green infrastructures might partly contribute to that $[75,124,125]$.

The physical-chemical properties of the substances are the main factor influencing their fate, both in terms of release into the environment and removal ability in wastewater treatment plants $[114,117,126-128]$. The octanol-water partition coefficient $\left(\log \mathrm{K}_{\mathrm{ow}}\right)$ and water solubility $\left(\mathrm{S}_{\mathrm{w}}\right)$ are critical parameters since they indicate the level of hydrophobicity and the tendency to bioaccumulate and adsorb, indicating hence the mobility of a substance in the environment. Substances with $\operatorname{low} \log \mathrm{K}_{\mathrm{ow}}$ values are more hydrophilic, with a higher tendency to dissolve in water and a lower tendency to adsorb on soil or bioaccumulate $[113,129]$. Additionally, to better describe their behavior, the soil-water partition coefficient $\left(\log \mathrm{K}_{\mathrm{oc}}\right)$ should be considered. It gives information about the mobility and adsorption of substances in soil. High values correspond to less mobile and highly absorbable substances showing higher tendencies to accumulate in soil.

In order to identify potential pathways of release/transport of the selected substances in the environment, part of the classification delineated in the NORMANN prioritization framework is applied [130] and the classification method is described in Table 4. According to the physical-chemical properties, the chemical substances are classified into four categories according to the properties, which correspond to a certain environmental pathway (Table 4). The result for each substance is shown in Table 3's column classification.

The substances classified in group 1 and 2 in Table 4 represent the hydrophilic substances, characterized by $\operatorname{low} \log \mathrm{K}_{\mathrm{ow}}$, rather high water solubility $\left(\mathrm{S}_{\mathrm{w}}\right)$, and $\operatorname{low} \log \mathrm{K}_{\mathrm{oc}}$ values. Therefore, the main pathway of their distribution in the environment is through aquatic systems. This could be confirmed in the literature; for instance, for mecoprop and 
carbendazim, which are classified in group 1 (see Table 3). These substances were detected in roof/facade leachate in concentrations of 1.5-4 and $40 \mu \mathrm{g} / \mathrm{L}$, respectively [126,131], and in untreated stormwater in ranges of total fraction of $0.51-6.9$ and $0.13-1.5 \mu \mathrm{g} / \mathrm{L}$, respectively [126,131-133]. A similar situation is described in the literature for other substances of these two groups, such as isoproturon, terbutryn, and tebuconazole. Slightly lower concentrations were detected in untreated stormwater in the consulted experimental cases for isoproturon (total fraction: $0.02-0.12 \mu \mathrm{g} / \mathrm{L}$ ) [131,133,134], for terbutryn (total fraction: 0.05-0.36 $\mu \mathrm{g} / \mathrm{L}_{-}[131,135]$, and for tebuconazole (total fraction: 0.02-0.09 $\mu \mathrm{g} / \mathrm{L}$ ) [131].

Table 4. Assessment of environmental fate, based on substances' properties.

\begin{tabular}{cccll}
\hline Group & $\log _{\mathbf{o w}}$ & $\mathbf{S}_{\mathbf{w}}$ & $\log _{\mathbf{o c}}$ & Category \\
\hline 1 & $\leq 3$ & $>1$ & $<3$ & water-related \\
2 & $<3-\leq 5$ & $>1$ & $<3$ & mainly water-related \\
3 & $>5$ & $<1$ & $>3$ & sediment-related \\
4 & $<3-\leq 5$ & $<1$ & $>3$ & mainly sediment-related \\
5 & $<3-\leq 5$ & $>1$ & $>3$ & water and/or sediment-related \\
6 & $<3-\leq 5$ & $<1$ & $<3$ & water and/or sediment-related \\
\hline
\end{tabular}

Similar to this, substances with high soil-water partitioning coefficients $\left(\log \mathrm{K}_{\mathrm{oc}}\right)$ and low water solubility exhibit a strong tendency to accumulate in soil or sediments and are classified as sediment-related substances (groups 3 and 4, Table 4). Therefore, those substances might be less likely to be emitted from GRs and VGSs during a storm event. However, their release cannot be neglected since storm events have the potential to wash out those pollutants as sediments/particulate matter and transport them through stormwater runoff or CSO to receiving waters. Moreover, this combination of properties indicates that the pollutants in combined sewers, once they have reached the WWTPs, are likely to be removed mainly by primary sedimentation treatment, since they will be adsorbed onto the particulate fraction and settled through gravity or else adsorbed onto the sludge.

Finally, for some substances classified in group 5 and 6 in Table 4, no specific pathway could be assigned, since they simultaneously show rather high solubility in water and high adsorbability in soil or low water solubility and low adsorbability in soil. In these cases, the fate after release from GRs and VGSs to treatment plants could follow the ways described in the previous two cases.

The half-life biodegradation is another important property for assessing the persistency of a substance in the environment. Regarding stormwater runoff, it could be an indicator of whether a substance might be degraded before the occurrence of a new storm event, which may reduce its release into the environment [74]. Therefore, in the final assessment of environmental fate, the half-life biodegradability in soil or sediment/water has to be considered for each substance (values in Table 3). According to [129], the recommended threshold for biodegradation, above which a given substance is considered persistent, is 40 days in freshwater and 120 days in soil. Nevertheless, a threshold of 20 days is considered in the following discussion, because this value represents a worst-case scenario of the average maximum number of consecutive dry days, based on the simulation made for Northern Europe by the European Environmental Agency [136]. Substances with a half-life of $>20$ days are supposed to be more persistent, or at least they are not degraded before the occurrence of the next storm event, and, therefore, they might be more likely to be released as a parent substance into the environment. Furthermore, half-life biodegradation could be a good indicator for assessing the removal of degraded substances in WWTPs. For instance, considering a symbolic low threshold of 5 days, these substances are likely to be degraded in WWTPs. The remaining substances with a half-life of $>5$ days might be badly degraded, and they might be removed by other methods, such as chemical precipitation, sedimentation, or filtration.

The half-life biodegradation values depend partly on the substance, but mainly on the matrix in which the experiments were performed. Therefore, caution should be taken 
when considering this property. To the best of the authors' knowledge, an overall and complete database with all the measured half-life values and their matrices is still missing.

Finally, the combination of this information (matrix of distribution and half-life) may allow for the identification of the most significant substances in terms of occurrence in the aquatic environment. The substances classified as water-related or mainly water-related and simultaneously showing a half-life of $>20$ days could be considered the most relevant substances among the selected ones in Table 3. The identified relevant substances are the following: mecoprop, carbendazim, ochtilinone, diuron, isoproturon, terbutryn, and terbuconazole. Since they are soluble in water, show a high degree of mobility in soil, and are not likely to be degraded before the occurrence of the following storm event, higher concentrations are expected to reach receiving waters, especially in cases of separated sewer systems. Furthermore, the greenery system might already behave as a barrier for the sediment-related group of substances (higher adsorption on soil, hence less likelihood of release), posing a lower risk to the aquatic environment compared with the waterrelated group. This information, combined with the environmental risk potential of these substances in the following section, helps with the identification of relevant pollutants emitted from GRs and VGSs to the aquatic environment.

Additionally, attention should be also paid to propiconazole and BPA (group 5 and 6). Due to their half-life biodegradation of greater than 20 days and the unspecified distribution pathway, they might be found in water as well.

\section{Environmental Risk Potential}

For the protection of the environment, the list of priority substances (PSs) and priority hazardous substances was issued as Article 10 of the WFD [137]. The parameters in the list of priority substances and hazardous priority substances (DIRECTIVE 2013/39/EU) [71] are selected according to the criteria of persistence, bioaccumulation, and toxicity (PBT criteria). For the very persistent and very bioaccumulative chemicals, the "secondary poisoning" after bioaccumulation or biomagnification will be considered, as there is concern that a substance has the potential to cause toxic effects if it has accumulated in higher organisms even if no toxicity is demonstrated in the laboratory.

The environmental quality standards (EQSs) are derived from toxicity data from three trophic levels (algae, daphnia, and fish) under consideration of an assessment factor (between 5 and 1000) depending on the database. They protect the pelagic communities, the sediment dwellers, and the top predators from secondary poisoning as well as indirectly protect humans from exposure to contaminated drinking water and the consumption of contaminated fish. For the risk characterization of a chemical substance, the predicted environmental concentration (PEC) is compared to the EQS. In the case that this ratio is $<1$, the substance is considered to be of no concern; otherwise, the risk must be managed. Due to the availability of data for the targeted pollutants, emission concentrations are used in this paper instead of the PEC.

As described in the previous sections, many substances have been identified (see Table 5) as potentially hazardous substances in surface runoff already emitted from GRs and VGSs. In this section, a prioritization is described according to the PBT criteria and environmental concentration. Specific concentrations in GR and VGS runoff, or in stormwater runoff, are used to estimate the MoE. The MoE is the ratio of (a) a reference point of (eco)toxicity to (b) the theoretical, predicted, or estimated exposure dose or concentration [138]. The MoE is commonly used in human health and environmental risk assessments.

We considered either the EQS from the Water Frame Directive [137] or the predicted no-effect concentration (PNEC) from the literature. As the EQS and the PNEC already cover three trophic levels and include an assessment factor accordingly, the EQS and PNEC could be directly compared with the predicted or measured environmental concentrations in the river. In that case, an MoE of 1 would be sufficiently protective. However, a larger MoE might be required if there are important data gaps or if the substance is carcinogenic, mutagenic, or toxic for reproduction (CMR). A smaller MoE may be considered 
appropriate if relevant human or animal data indicate that a lower factor is appropriate for interspecies extrapolation. In this study, due to the lack of data, runoff concentrations were compared with the EQS. Because runoff is diluted in the receiving water, a dilution ratio of 1:10 at the point of compliance is proposed [139]. An MoE below 0.1 may be assumed as critical for non-CMR (substances classified as carcinogenic, mutagenic, or toxic for reproduction (CMR)) and non-endocrine-disruptive substances (non-EDSs). Endocrine-disruptive substances (EDSs) should be given particular attention as, under $\mathrm{REACH}$, endocrine disruptors have been identified as substances of very high concern alongside with CMR chemicals [140].

For the following calculation of $\mathrm{MoE}$, the highest and lowest concentrations of GR and VGS runoff (Table 5) were considered. In addition, MoEs were also calculated for stormwater concentrations. These runoff concentration values were preferably compared to EQS values, and, if these were not available, to PNEC values.

As can be seen in Table 5, the concentrations of the target substances in stormwater runoff differ considerably, while very limited information is available in the literature regarding pollutant concentrations in runoffs from GRs and VGSs. Due to the lack of data in the literature for many substances regarding their emission from GRs and VGSs, it was not possible to calculate a MoE for these compounds.

Regarding metals, it could be shown that $\mathrm{Cu}$ and $\mathrm{Zn}$ in particular, but also $\mathrm{Cr}$, are emitted in concentrations exceeding the lowest EQS, and their MoE calculated based on GR and VGS runoff is $<1$ (worst-case scenario: 0.017 for $\mathrm{Cu}$ and $\mathrm{Zn}$ ). In contrast to this, the $\mathrm{MoE}$ calculated in the same way for $\mathrm{Cd}, \mathrm{Ni}$, and $\mathrm{Pb}$ is $>1$. It should be mentioned that this calculation is based on a limited data set. Considering the MoE values calculated based on maximum concentrations in stormwater runoff, the MoE values for all relevant metals are $<1$ (the $\mathrm{MoE}$ values for $\mathrm{Cr}, \mathrm{Cu}, \mathrm{Pb}$, and $\mathrm{Zn}$ are also $<0.1$ ). Therefore, they should be considered as pollutants of concern for receiving waters and strategies for their mitigation in stormwater runoff are strongly recommended. In the case of organic micropollutants, the MoE is especially low ( $<0.1$ for the pesticides cybutryne, terbutryn, diuron, and carbendazim) when emitted concentrations from GRs and VGSs are considered. Considering the data on stormwater runoff, the MoE values for these substances are much higher and close to or above 1. Furthermore, most of them (terbutryn, diuron, and carbendazim) were identified as relevant substances regarding their occurrence in the aquatic environment according to their physical-chemical properties in the previous section.

Consequently, these substances should also be considered as relevant pollutants potentially originating from GR and VGS runoff. Attention should also be paid to the group of alkylphenols. Nonylphenol (NP) and octylphenol (OP) are classified as substances of very high concern and included in the candidate list for authorization because of their endocrine-disrupting properties. For OP, the MoE values calculated for GR and VGS runoff are lower than those from stormwater runoff; nevertheless, mitigation measures should be developed for alkylphenols for both stormwater and GR and VGS runoff due to the stricter $\mathrm{MoE}$ for EDS. Data from stormwater runoff indicate that, for some of the data, the MoE for BPA and DEHP is lower than 1, which means that these substances should be considered as relevant regarding further measures. For PBDE, only low environmental concentrations were found in the literature for GR and VGS runoff and stormwater, resulting in an accordingly high MoE. This can lead to the interpretation that this group of substances may not be prioritized for mitigation measures, which is of limited validation because of the data scarcity for their emission from GRs and VGSs.

From the evaluation in the "Environmental Risk Potential" section, it could be seen that $\mathrm{Cu}, \mathrm{Zn}, \mathrm{Cr}$, and pesticides/biocides showed the lowest MoE values. Therefore, particular attention should be given to the mitigation strategies of the runoff from GRs and VGSs for these groups of substances. 
Table 5. Comparison of environmental concentrations in runoff from stormwater and GRs and VGSs to the EQS (PNEC) and calculation of MoE.

\begin{tabular}{|c|c|c|c|c|c|c|c|c|c|}
\hline & & $\begin{array}{c}\text { Environmental } \\
\text { Concentration in } \\
\text { Untreated } \\
\text { Stormwater } \\
\text { Runoff }(\mu \mathrm{g} / \mathrm{L}) \\
\end{array}$ & Literature & $\begin{array}{c}\text { Environmental } \\
\text { Concentrations } \\
\text { in GR and VGS } \\
\text { Runoff }(\mu \mathrm{g} / \mathrm{L})\end{array}$ & Literature & $\begin{array}{l}\mathrm{EQS}^{1} \\
(\mu \mathrm{g} / \mathrm{L})\end{array}$ & $\begin{array}{c}\text { PNEC }^{2} \\
\text { Fresh- } \\
\text { Water } \\
(\mu \mathrm{g} / \mathrm{L})\end{array}$ & $\begin{array}{c}\text { MoE } \\
\text { (Stormwater) }\end{array}$ & $\begin{array}{l}\text { MoE (GR and } \\
\text { VGS) }\end{array}$ \\
\hline \multicolumn{10}{|c|}{ Heavy Metals } \\
\hline $7440-43-9$ & $\mathrm{Cd}$ & $0.019-30$ & {$[131,132,134,135,141-146]$} & $0.05-0.1$ & {$[17,40,52]$} & $\begin{array}{l}0.45 \text { (class } \\
1 \text { ) }\end{array}$ & 0.19 & $0.112-23.67$ & $4.5-9$ \\
\hline $7440-47-3$ & $\mathrm{Cr}$ & $0.25-94$ & {$[125,131,132,134,135,141,143,144,146,147]$} & $0.9-8.1$ & [40] & 3.4 & 6.5 & $0.036-13.6$ & $0.42-3.78$ \\
\hline $7440-50-8$ & $\mathrm{Cu}$ & $1.2-352$ & {$[125,131,132,134,135,141,143-148]$} & $0.02-58$ & {$[17,40,52,56,61]$} & $1.00-28$ & 7.8 & $\begin{array}{l}0.0028-0.83 ; \\
0.08-23.33\end{array}$ & $\begin{array}{l}50-0.017 \\
0.48-1400\end{array}$ \\
\hline 7439-92-1 & $\mathrm{Pb}$ & $0.95-300$ & {$[125,131,132,134,135,141-148]$} & $0.0025-6$ & {$[17,52,61]$} & 14 & 2.4 & $0.047-14.73$ & $2.3-5600$ \\
\hline $7440-02-0$ & $\mathrm{Ni}$ & $0.91-130$ & {$[131,132,134,135,141,143,144,146]$} & $0.6-3.5$ & {$[17,40,52]$} & 34 & 7.1 & $0.26-37.36$ & $9.71-56.6$ \\
\hline $7440-66-6$ & $\mathrm{Zn}$ & $4-2000$ & {$[125,132,134,135,142-148]$} & $0.06-468$ & {$[17,40,52,56,61]$} & $8.0-25$ & 20.6 & $\begin{array}{c}0.004-2 ; \\
0.012-6.25\end{array}$ & $\begin{array}{c}0.017-133 ; \\
0.06-417\end{array}$ \\
\hline \multicolumn{10}{|c|}{ Biocides/Herbicides } \\
\hline $93-65-2$ & Mecoprop & $0.51-6.9$ & [131] & $1-10$ & {$[149,150]$} & 3.6 & & $0.52-7.06$ & $3.6-0.36$ \\
\hline $10605-21-7$ & Carbendazim & $0.13-1.5$ & [131] & 40 & {$[149,150]$} & 0.34 & & $0.23-2.6$ & 0.0085 \\
\hline 55406-53-6 & PBC & & & & & & 0.53 & & \\
\hline $2634-33-5$ & BIT & $0.09-1.6$ & [131] & & & & 4.03 & & \\
\hline 2682-20-4 & MIT & & & & & & 3.39 & & \\
\hline $26530-20-1$ & OIT & & & $20-14,000$ & [151] & & & & \\
\hline $330-54-1$ & Diuron & $0.055-1.21$ & [131-135] & 70 & [149] & 1.8 & 320 & $1.48-32.7$ & 0.026 \\
\hline $34123-59-6$ & IP & $0.02-0.12$ & {$[131,133,134,141,152]$} & & & 1 & & $8.33-50$ & \\
\hline $\begin{array}{l}52645-53-1 \\
8001-54-5\end{array}$ & $\begin{array}{l}\text { Permethrin } \\
\text { BZC }\end{array}$ & $0.005-0.017$ & {$[153]$} & & & & & & \\
\hline 28159-98-0 & Cybutryne & $0.01-0.02$ & [131] & $7000-12,000$ & {$[76,149]$} & 0.016 & & $0.8-1.6$ & $\begin{array}{l}0.00000133- \\
0.00000228\end{array}$ \\
\hline $886-50-0$ & Terbutryn & $0.05-0.36$ & {$[131,135]$} & $360-1000$ & {$[76,149,154]$} & 0.34 & & $0.94-6.8$ & $0.00034-0.00094$ \\
\hline $60207-90-1$ & Propiconazole & 0.04 & [16] & & & & & & \\
\hline 107534-96-3 & Tebuconazole & $0.02-0.09$ & [131] & & & & & & \\
\hline
\end{tabular}


Table 5. Cont.

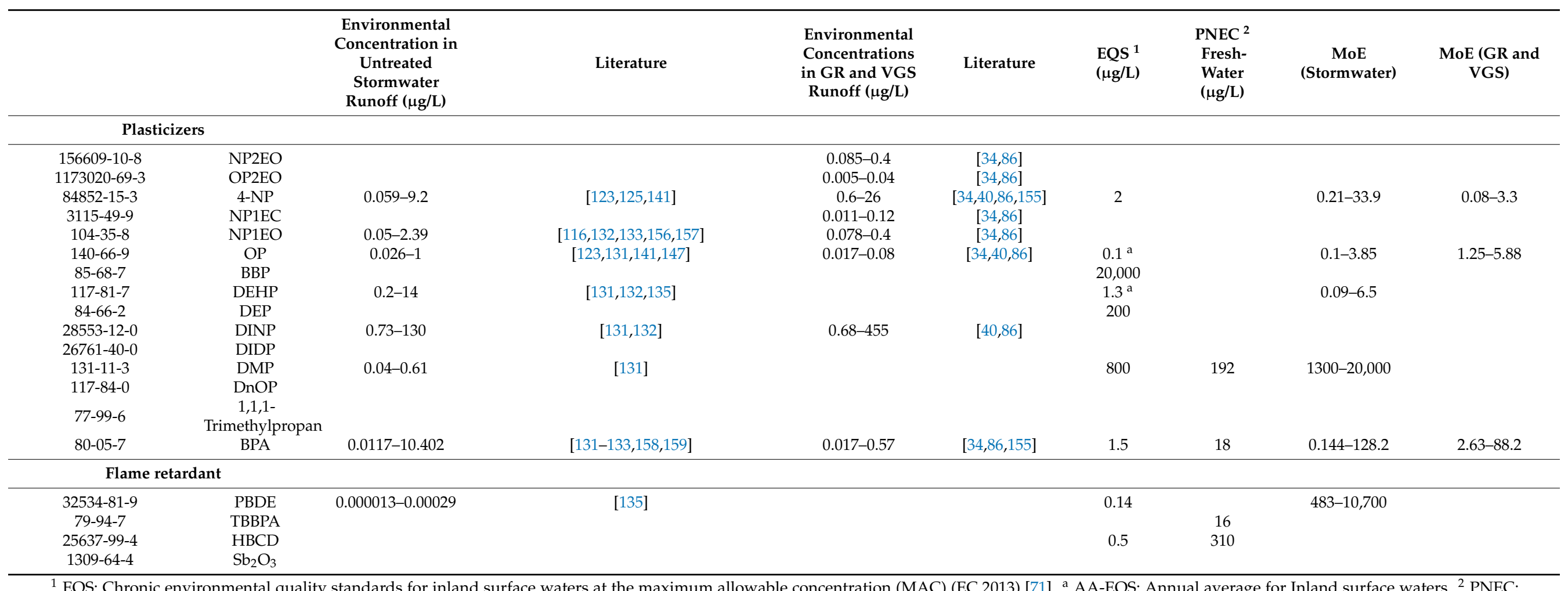

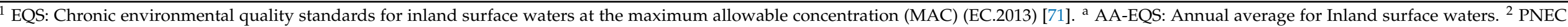
predicted no-effect concentration. 


\section{Mitigation Strategies}

GR and VGS installations provide aesthetic, economic, and environmental benefits and contribute to mitigating the effects of climate change in urban areas [160]. However, based on the information collected and the assumptions made in the previous sections ("Pollutants' Environmental Fate" and "Environmental Risk Potential"), it can be expected that GRs and VGSs could partly contribute to the emission of certain pollutants (used in materials or for pest control) into the urban runoff.

Since GRs and VGSs are among the measures for stormwater quantity and quality management, other recommendations for mitigating their environmental impact through runoff are needed. Two mitigation approaches can be suggested:

- Mitigation at the source, through:

- optimization of construction practices of green elements and/or materials used; and

$\circ \quad$ use of decentralized treatments; and

- Conventional mitigation-centralized treatment in stormwater TPs and WWTPs

We specifically focus on mitigation approaches at the source since they directly contribute to reducing and/or avoiding the release of the pollutants before they enter the aquatic system.

\subsection{Mitigation at the Source-Optimization of Construction Practices and Materials Used}

The choice of materials, the type of vegetation used, and the type of GR and VGS have a significant impact on the release of pollutants from green buildings, influencing the stormwater runoff quality $[17,54]$. Therefore, the first step to mitigating the release of pollutants from GRs and VGSs should be directed towards improving the performance of these materials.

For instance, in terms of types of GR and VGS influencing the runoff mitigation and modification of the quality of the runoff water, intensive GRs function much better than extensive GRs because of differences in their conception and composition. Extensive GRs could lead to $60 \%$ runoff mitigation while intensive GRs achieve up to $100 \%$ runoff mitigation [160]. In addition, Berndtsson et al. [62] reported an experimental study of green roof models and indicated that the lead, zinc, cadmium, and copper contamination levels in the runoff from intensive GRs are significantly lower than those of the runoff from extensive ones [62].

As mentioned previously, intensive GRs seem to be well-suited for reducing emissions for certain pollutants (e.g., metals) due to their physical-chemical properties (high $\log \mathrm{K}_{\mathrm{ow}} / \mathrm{K}_{\mathrm{oc}}$; tendency to accumulate in soil). The high depth of GM of intensive GRs might be a suitable choice for the group of substances categorized as (mainly) sedimentationrelated. Due to their high partitioning coefficient and low water solubility, they tend to accumulate in the substrate and their emission during storm events is limited. A deep substrate might also be feasible for the (mainly) water-related substances with high degradability (half-life $<20$ days) because of the longer retention time in a deep substrate, which can positively influence the biodegradability of these pollutants.

The GM used can influence the release of pollutants as well; therefore, its selection should be considered when evaluating the GR and VGR runoff water quality [161,162]. Long et al. [162] compared the loads of different pollutants (nutrients, $\mathrm{Cu}, \mathrm{Pb}$, and $\mathrm{Cd}$ ) from four different media: expanded clay with and without additives, expanded slate, and medium and fine-grade expanded shales. The expanded shale and clay-based media performed better for pollutant mitigation, in particular for heavy metals [162]. Köhler et al. [161] also recommended that an appropriate choice of GM composition can contribute to a significant reduction in pollution in receiving waters. They observed that combining the strengths of two different GM, a sand-lava-pumice mix (higher water retention due to the grain size) and an expanded slate (lower turbidity and electrical conductivity in runoff; hence, low pollutant release), would increase pollutant retention [161]. Despite the fact 
that their study focused mainly on nutrient release, this particular case might be suitable for the water-related group of pollutants. Their high water solubility makes their release into the environment possible during storm events.

The GR runoff water quality might further be improved by using different types of vegetation [161]. For instance, Alsup et al. [17] demonstrated that the presence of a Sedum hybridum plant decreased the leaching of $\mathrm{Pb}$ and that the leaching of $\mathrm{Cd}$ was generally enhanced by vegetation for most growing media over time [17].

The type and properties of the materials used (e.g., root barrier) affect the GR and VGS water runoff as well $[54,149]$. Optimizing their use with regard to leaching performance is also part of the mitigation-at-source approach. For instance, the use of coated materials instead of uncoated ones could decrease or eliminate emissions of unwanted substances from rooftops directly at the source. As mentioned in Section 3.1, it was observed that coated metal in roofing could reduce emissions by up to two orders of magnitude in comparison with uncoated metal $[65,67]$ for mecoprop $(\sim 44 \mu \mathrm{g} / \mathrm{L}$ instead of $100 \mu \mathrm{g} / \mathrm{L})$. A different coating material for bitumen sheets changes their leaching behavior as well. An overall lower leaching concentration for mecoprop was measured from a talcum-sand coating when compared with a shale coating [54]. By replacing the initially used glycole ester (Preventol B2) with a more difficult to hydrolyze ester, e.g., the 2-ethylhexyl ester (Herbitect ${ }^{\circledR}$ and Preventol ${ }^{\circledR}$ B5), the leaching of mecoprop in runoff could be reduced by up to 20 times [82]. In combination with a limited usage of bituminous layers containing this substance, a further reduction in mecoprop emissions to surface runoffs of up to 50 times could be achieved [54]. These results show clearly that source control and modification of the materials used is a successful approach to limiting the runoff pollution. Another way to prevent water-soluble biocides/pesticides from leaching directly at the source is nanotechnological encapsulation. By providing long-term protection of the structure of the substances, this technique could release them slowly and hence could prolong their lifetime [163]. For instance, this encapsulation could preserve the biocidal activity even under temperature and $\mathrm{pH}$ conditions at which decomposition and hydrolysis would otherwise occur [163].

Overfertilization can lead to high nutrient amounts in GM and influence not only the plant performance but also the nutrient leaching to the environment. Roof aging contributes to nutrient leaching as well. Thus, there is a need to suggest appropriate fertilizer application rates to avoid negative environmental impacts [164]. Overall, fertilization of GR modules can be adopted as a standard GR maintenance procedure without negatively impacting environmental water quality if appropriate fertilizer rates and types are used in accordance with the nutrient composition of the GM [164].

The current technical and scientific knowledge regarding VGSs remains fragmented. To the best of our knowledge, no literature or research studies on the leaching of pollutants from GRs and VGSs have been published to date. However, based on the knowledge gained from GRs, similar effects can be expected for VGSs if the same materials are used. Therefore, similar optimization approaches to mitigate pollution leaching might be applied (e.g., the use of different materials, coatings, and encapsulation).

\subsection{Mitigation at the Source-Decentralized Treatment Options}

The reduction of pollution emissions through a reasoned choice of the material/vegetation/growing medium used is rather limited, since one must reckon with the existing architectural rules, the harmonization of urban landscapes, and the availability of materials. Therefore, it is important to develop solutions for the treatment or capture of pollutants emitted by GRs and VGSs directly before or below the gutter, close to the pollution source $[65,165]$.

One approach to reducing environmental pollution emissions before they enter the aquatic environment is the use of technical filters for the purification of roof runoff, which is applied in many European countries. In this context, a targeted standard procedure was launched in 2016 in Austria (ÖNORM B2506-3) [166] for testing of the substrate regarding its 
ability to purify rainwater from roof gutters and reinforced surfaces-among others-also regarding the heavy metals $\mathrm{Cu}, \mathrm{Pb}$, and $\mathrm{Zn}$. These technical filter systems, which are already available on the market, can also be applied for the purpose of eliminating heavy metal emissions from GRs and VGSs if necessary. This decentralized treatment option would be ideal for the group of sediment-related substances showing high adsorbability potential.

A few studies show promising results concerning the direct treatment or capture of pollutants (before the gutter or at the gutter base). Most of them are based on adsorption techniques on zeolites or granular activated carbon or anthracite or vermiculite into the substrate to limit nutrient leaching and metals from GRs $[142,167,168]$. For instance, Boller et al. [142] observed that the application of an infiltration trench, made of iron peroxide and situated directly underneath the end of a copper facade, showed very good adsorption removal for $\mathrm{Cu}(95 \%-99.7 \%)$. Al-Anbari et al. [167] introduced a new stormwater harvesting technology composed of porous perma-pavement on top, a substrate underneath, and a PET storage tank on the side. They observed that the best single media filters in terms of adsorptive capacity of nutrients and heavy metals were granular activated carbon, anthracite, vermiculite, and zeolite and, consequently, the best combination of those was made of granular activated carbon and zeolite in equal parts [167]. Biochar has been suggested as a means of retaining nutrients in the GR substrate $[169,170]$.

Other decentralized treatments for stormwater runoff are treatment wetlands combined with GRs themselves, bioswales, bioretention systems, infiltration features (e.g., vegetated filter strips), porous pavement, settling, and detention basins. Excluding GRs, the rest may be also applicable for GR/VGS runoff quality treatment. Some of them, such as stormwater detention basins, may show lower removal/retention performance for more hydrophilic substances (water-related) compared with other methods. This is because, in detention basins, sedimentation/settling occurs; therefore, water-related substances that are mainly found in dissolved phase have a lower possibility to settle [171]. Some other technologies, such as constructed wetlands, bioswales, and bioretention basins, require a large amount of space to operate; hence, they might not be feasible as down-the-gutter treatment option or in most urban situations [167]. Therefore, the focus should be directed towards systems and system combinations that are suitable in the urban context. For instance, Bester et al. [172] simulated and studied the performance of an activated soil filter at a pilot scale to remove certain hydrophilic/moderate hydrophobic biocides leaching from buildings during storm events (simulating low and high flow conditions). The filter was composed of three layers (peat, sand, and gravel) and reed was planted on top (Phragmites australis) [172]. Some of the substances identified as relevant in this study (the water-related group), such as terbutryn, isoproturon, and diuron, were very well removed during low flow conditions (mean removal rates of 100, 99, and 97\%, respectively) [172]. However, during simulated high flow conditions the removal efficiency overall decreased [172]. Nevertheless, the additional equipment of existing soil retention filters with organic-rich layers, such as peat, might be a feasible decentralized treatment method to at least reduce the direct discharge into water bodies, in particular for those substances grouped as (mainly) water-related. Braswell et al. [173] studied the performance of a stormwater control measure composed of permeable interlocking concrete pavement discharging into a proprietary box filter (a biofilter). This combination of measures showed both very good and good removal behavior for total suspended solids (96\%) and total phosphorus (75\%), respectively [173]. This design would be suitable for down-the-gutter urban situations and the high degree of removal of suspended solids indicates that it might be a feasible treatment option for the group of sediment-related substances. Once washed out during strong storm events, they might be collected through porous pavement and treated by biofiltration through sedimentation or physical filtration [165]. Another example of stormwater treatment using biofiltration swales and vegetative filter strips was studied by [165]. They compared the road runoff treatment efficiency of both systems, and the vegetated filtration strip showed a higher removal capacity than the biofiltration swale for heavy metals, BPA, and octylphenol, but rather low removal rates for nonylphenol 
monoethoxylate and phthalates [165]. Nevertheless, in terms of urban suitability and for the group of sediment-related substances, vegetated filter strips might be considered as a possible stormwater management method. Furthermore, if not present directly in the growing media, such as biochar, geomedia amendments to best management practices (BMPs) (e.g., carbonaceous adsorbents, engineered reactive geomedia, zeolite, manganese oxidecoated sand, activated carbon, or biochar-amended biofilters) might be a useful additional treatment step to improve the removal of hydrophilic substances (the water-related group) in decentralized systems treating stormwater runoff [171]. For instance, Ashoori et al. [174] tested the efficiency of a pilot-scale sand filter amended with biochar and woodchips, or woodchips alone or woodchips and straw, to remove hydrophilic substances. They showed that the biochar-amended reactor fully removed the pollutants during the experiments, including diuron [174].

Among the processes that might reduce pollutant concentrations, biodegradation seems to be a possibility for most of the selected biocides. Additionally, UV light can strongly increase the degradation of MIT and BIT [175]. However, degradation byproducts should not be underestimated, since they might be even more toxic than the parent ones [163].

\subsection{Mitigation at the End-of-Pipe-Conventional Centralized Treatment Options}

In the case of combined sewer systems, if no mitigation option could be installed at the source, the portion of collected stormwater (also partly originating from green infrastructures) that is not released into the receiving water body at the CSO point is mixed with raw sewage and ends up in WWTPs. Here, conventional treatment options are used. In brief, for the group of sediment-related substances the dominant removal pathway in WWTPs is sedimentation due to their presence in the particulate fraction. The particles passing the sedimentation might be integrated or adsorbed within the activated sludge matrix and hence taken out with the excess sludge. The dissolved substances, if they are well degradable, might be reduced by biological oxidation, or otherwise by further treatments such as chemical precipitation or filtration.

In the case of separate sewers and for the released portion at CSO points, there is a growing need to install stormwater treatment plants as centralized options in order to meet the requirements of the water quality standards for the receiving waters (derived from E.U. Water Framework Directive, 2000) [137]. The technologies used here are the same as for the above-described decentralized treatment options, such as bioretention filters. However, the treatment efficiency will suffer in the case of end-of-pipe solutions if all pollutants from the different sources within the total catchment are fully mixed and the resulting hydraulic load will lead to massive installations.

In the case of GRs/VGSs, conventional treatment (mitigation at the end-of-pipe) should be considered as a final option, if possible. The city of Berlin serves as an example of the benefits of using decentralized treatment options: the presence of combined and separated sewer systems and, therefore, the final conventional treatment approach led to receiving waters of poor quality during summer (eutrophication) [176]. However, with the higher use of decentralized treatments the receiving water's quality significantly improved, proving that direct and near-the-source treatment might be a better solution [176].

\section{Conclusions}

Even if the scientific literature addressing developments in GRs and VGSs has systematically grown during the last 20 years, there remains only limited information on their impact on surface runoff quality in urban areas. Out of 1166 publications in total (803 for GRs and 363 for VGSs), only a limited number (71 publications) fit the scope of this review paper. The results of our literature search highlight an existing research gap concerning the knowledge about potential environmental pollutants originating from GRs and VGSs. Therefore, the authors are of the opinion that the database needs to be improved and more investigations are still needed regarding this topic. 
Based on descriptions of the GRs and VGSs already established on the market, detailed information about the materials used for their construction could be collected (Table 2). It was identified that most of the materials used are plastic-based, followed by metal-based materials, as support and structural elements. Numerous materials are used as components of the growing medium or additives to support the vegetation (mineral- or organic-based). The potential pollutants that can originate from these materials were identified and are described in Table 3.

Regarding the impact of GRs and VGSs on surface runoff quality, a total number of 41 chemical substances were identified as pollutants that may be emitted from these systems. These were classified into three main groups: metals, additives, and nutrients.

The assessment of the environmental fate of the identified pollutants (with the exception of nutrients) was performed based on their physical-chemical properties and their expected behavior under the specific conditions in GRs and VGSs. Assuming that these systems provide a barrier for particulate pollution (sediment-related groups), the identification of the most relevant substances, in terms of likelihood of occurrence in the aquatic environment, was focused on the water-related groups. Their high solubility in water, high mobility (low adsorbability), and high biodegradability in soil classify their potential release pathway as being through (mainly) water. The identified substances are: mecoprop, carbendazim, ochtilinone, diuron, isoproturon, terbutryn, and terbuconazole. Additionally, attention should be paid to BPA and propiconazole due to their unspecified pathway release and high biodegradability in soil.

As the next step, an estimation of the environmental risk potential of the targeted pollutants was made based on the calculation of margins of exposure for each substance. For metals such as $\mathrm{Cu}, \mathrm{Zn}$, and $\mathrm{Cr}$, emissions from GRs and VGSs are considered to be of special relevance regarding environmental quality standards in surface waters. $\mathrm{Cd}$, $\mathrm{Cr}, \mathrm{Cu}, \mathrm{Ni}, \mathrm{Pb}$, and $\mathrm{Zn}$ were identified as relevant emissions from stormwater. Strategies for their mitigation in GRs, VGSs, and stormwater runoff are strongly recommended. Regarding additives, special attention should be paid to biocides/herbicides and the group of alkylphenols.

For the mitigation of emissions of targeted pollutants, it is of special importance to direct the focus first to measures at the source. The optimization of materials and construction of GRs and VGSs may help to reduce or even entirely avoid (or eliminate) the unwanted release of substances into the aquatic system. Appropriate decentralized stormwater treatment measures (porous pavement, infiltration trenches, biofiltration, etc.) might also reduce the amount of pollutants at the source that otherwise would end up in groundwater or receiving water bodies. Only as a final option should the conventional (centralized) end-of-pipe treatment be considered, especially for those persistent substances and in the case of combined sewer overflows.

Finally, based on the results of this review, the authors believe that the urgency to address the topic of the impact of GRs and VGSs on surface runoff quality will likely drive further development and innovation in the GR and VGS industry and drive the establishment of environmental regulations for urban GRs and VGSs.

Author Contributions: Conceptualization, R.A.; methodology, I.H. and B.P.; formal analysis, R.A. and I.H; investigation, I.H., E.D.V.-F. and F.P.; data curation, R.A. and M.F.; writing-original draft preparation, I.H., E.D.V.-F., F.P., B.P. and M.F.; writing—review and editing, G.L., T.E., B.P. and R.A.; visualization, F.P.; supervision, R.A.; funding acquisition, I.H. All authors have read and agreed to the published version of the manuscript.

Funding: This research was supported by the Austrian Agency for Education and Internationalisation (OeAD) through an Ernst Mach Grant for the first author; grant number ICM-2020-00087. The APC was paid by the COST Action CA17133 Circular City, supported by COST (European Cooperation in Science and Technology). www.cost.eu.

Institutional Review Board Statement: Not applicable.

Informed Consent Statement: Not applicable. 
Acknowledgments: The support from the Doctoral School HR21 (BOKU University Vienna, Austria) for Pucher Bernhard is very much appreciated. The authors acknowledge the support of the project "Urban Vertical Greening 2.0: Vertical greening for livable cities-co-create innovation for the breakthrough of an old concept" under the SUGI-FWE Nexus JPI Urban Europe, grant number 16485002.

Conflicts of Interest: The authors declare no conflict of interest.

\section{References}

1. Lavell, A.; Oppenheimer, M.; Diop, C.; Hess, J.; Lempert, R.; Li, J.; Muir-Wood, R.; Myeong, S.; Moser, S.; Takeuchi, K.; et al. Climate Change: New Dimensions in Disaster Risk, Exposure, Vulnerability, and Resilience: A Special Report of Working Groups I and II of the Intergovernmental Panel on Climate Change (IPCC). In Managing the Risks of Extreme Events and Disasters to Advance Climate Change Adaptation: Special Report of the Intergovernmental Panel on Climate Change; Cambridge University Press: Cambridge, UK; New York, NY, USA, 2012; pp. 25-64. [CrossRef]

2. Oke, T.R. The energetic basis of the urban heat island. Q. J. R. Meteorol. Soc. 1982, 108, 1-24. [CrossRef]

3. Vicedo-Cabrera, A.M.; Scovronick, N.; Sera, F.; Royé, D.; Schneider, R.; Tobias, A.; Astrom, C.; Guo, Y.; Honda, Y.; Hondula, D.M.; et al. The burden of heat-related mortality attributable to recent human-induced climate change. Nat. Clim. Chang. 2021, 11, 492-500. [CrossRef]

4. Pearlmutter, D.; Pucher, B.; Calheiros, C.S.C.; Hoffmann, K.A.; Aicher, A.; Pinho, P.; Stracqualursi, A.; Korolova, A.; Pobric, A.; Galvão, A.; et al. Closing Water Cycles in the Built Environment through Nature-Based Solutions: The Contribution of Vertical Greening Systems and Green Roofs. Water. 2021, 13, 2165. [CrossRef]

5. Fletcher, T.D.; Shuster, W.; Hunt, W.F.; Ashley, R.; Butler, D.; Arthur, S.; Trowsdale, S.; Barraud, S.; Semadeni-Davies, A.; BertrandKrajewski, J.-L.; et al. SUDS, LID, BMPs, WSUD and more-The evolution and application of terminology surrounding urban drainage. Urban. Water J. 2015, 12, 525-542. [CrossRef]

6. Yin, D.; Chen, Y.; Jia, H.; Wang, Q.; Chen, Z.; Xu, C.; Li, Q.; Wang, W.; Yang, Y.; Fu, G.; et al. Sponge city practice in China: A review of construction, assessment, operational and maintenance. J. Clean. Prod. 2021, 280, 124963. [CrossRef]

7. Simperler, L.; Ertl, T.; Matzinger, A. Spatial Compatibility of Implementing Nature-Based Solutions for Reducing Urban Heat Islands and Stormwater Pollution. Sustainability. 2020, 12, 5967. [CrossRef]

8. Langergraber, G.; Pucher, B.; Simperler, L.; Kisser, J.; Katsou, E.; Buehler, D.; Mateo, M.C.G.; Atanasova, N. Implementing nature-based solutions for creating a resourceful circular city. Blue-Green Syst. 2020, 2, 173-185. [CrossRef]

9. Atanasova, N.; Castellar, J.A.; Pineda-Martos, R.; Nika, C.E.; Katsou, E.; Istenič, D.; Pucher, B.; Andreucci, M.B.; Langergraber, G. Nature-Based Solutions and Circularity in Cities. Circ. Econ. Sustain. 2021, 1, 319-332. [CrossRef]

10. Gräf, M.; Immitzer, M.; Hietz, P.; Stangl, R. Water-Stressed Plants Do Not Cool: Leaf Surface Temperature of Living Wall Plants under Drought Stress. Sustainability. 2021, 13, 3910. [CrossRef]

11. Allabashi, R.; Haile, T.M.; Fuerhacker, M.; Pitha, U.; Scharf, B.; Stach, W.; Ziegenbalg, F.; Heidinger, S.; Ertl, T. Simultaneous removal of heavy metals from synthetic storm water using sustainable urban drainage systems. Urban. Water J. 2019, 16, 444-450. [CrossRef]

12. Blecken, G.-T.; Marsalek, J.; Viklander, M. Laboratory Study of Stormwater Biofiltration in Low Temperatures: Total and Dissolved Metal Removals and Fates. Water Air Soil Pollut. 2011, 219, 303-317. [CrossRef]

13. Hatt, B.E.; Fletcher, T.D.; Deletic, A. Hydraulic and pollutant removal performance of stormwater filters under variable wetting and drying regimes. Water Sci. Technol. 2007, 56, 11-19. [CrossRef]

14. Hatt, B.E.; Steinel, A.; Deletic, A.; Fletcher, T.D. Retention of heavy metals by stormwater filtration systems: Breakthrough analysis. Water Sci. Technol. 2011, 64, 1913-1919. [CrossRef]

15. Alsup, S.; Ebbs, S.; Battaglia, L.; Retzlaff, W. Green Roof Systems as Sources or Sinks Influencing Heavy Metal Concentrations in Run. off. J. Environ. Eng. 2013. [CrossRef]

16. Paijens, C.; Bressy, A.; Frère, B.; Moilleron, R. Biocide emissions from building materials during wet weather: Identification of substances, mechanism of release and transfer to the aquatic environment. Environ. Sci. Pollut. Res. Int. 2020, $27,3768-3791$. [CrossRef]

17. Alsup, S.; Ebbs, S.; Retzlaff, W. The exchangeability and leachability of metals from select green roof growth substrates. Urban. Ecosyst. 2010, 13, 91-111. [CrossRef]

18. Pearlmutter, D.; Theochari, D.; Nehls, T.; Pinho, P.; Piro, P.; Korolova, A.; Papaefthimiou, S.; Mateo, M.C.G.; Calheiros, C.; Zluwa, I.; et al. Enhancing the circular economy with nature-based solutions in the built urban environment: Green building materials, systems and sites. Blue-Green Syst. 2020, 2, 46-72. [CrossRef]

19. Castellar, J.A.C.; Popartan, L.A.; Pueyo-Ros, J.; Atanasova, N.; Langergraber, G.; Säumel, I.; Corominas, L.; Comas, J.; Acuña, V. Nature-based solutions in the urban context: Terminology, classification and scoring for urban challenges and ecosystem services. Sci. Total Environ. 2021, 779, 146237. [CrossRef]

20. Langergraber, G.; Castellar, J.A.; Pucher, B.; Baganz, G.F.; Milosevic, D.; Andreucci, M.B.; Kearney, K.; Pineda-Martos, R.; Atanasova, N. A Framework for Addressing Circularity Challenges in Cities with Nature-based Solutions. Water. $2021,17,2355$. [CrossRef] 
21. Özyavuz, M.; Karakaya, B.; Ertin, D.G. The Effects of Green Roofs on Urban Ecosystems. Conference: Green Age Symp. 2015, 1-9. Available online: https://www.researchgate.net/publication/315792406_The_Effects_of_Green_Roofs_on_Urban_Ecosystems (accessed on 1 September 2021).

22. Weiler, S.; Scholz-Barth, K. Green Roof Systems: A Guide to the Planning Design and Construction of Landscapes over Structure; John Wiley \& Sons: Hoboken, NJ, USA, 2009; pp. 92-93.

23. Grant, G.; Gedge, D. Living roofs and walls from policy to practice: 10 years of urban greening in London and beyond. In Report of the European Federation of Green Roof and Green Wall Associations (EFB) and Livingroofs. org on Behalf of the Greater London Authority; Blanche Cameron of The Bartlett, University College London (UCL): London, UK, 2019.

24. Manso, M.; Castro-Gomes, J. Green wall systems: A review of their characteristics. Renew. Sustain. Energy Rev. 2015, 41, 863-871. [CrossRef]

25. Ottelé, M.; Perini, K.; Fraaij, A.; Haas, E.M.; Raiteri, R. Comparative life cycle analysis for green façades and living wall systems. Energy Build. 2011, 43, 3419-3429. [CrossRef]

26. Cortês, A.; Almeida, J.; de Brito, J.; Tadeu, A. Water retention and drainage capability of expanded cork agglomerate boards intended for application in green vertical systems. Constr. Build. Mater. 2019, 224, 439-446. [CrossRef]

27. Oquendo-Di Cosola, V.; Olivieri, F.; Ruiz-García, L.; Bacenetti, J. An environmental Life Cycle Assessment of Living Wall Systems. J. Environ. Manag. 2020, 254, 109743. [CrossRef] [PubMed]

28. Natarajan, M.; Rahimi, M.; Sen, S.; Mackenzie, N.; Imanbayev, Y. Living wall systems: Evaluating life-cycle energy, water and carbon impacts. Urban Ecosyst. 2015, 18, 1-11. [CrossRef]

29. Pucher, B.; ZluwA, I. Entwicklung Eines Multifunktionalen Living-Wall-Systems zur Reinigung und Nutzung von Grauwasser; Wasser und Abfall: Hennef, Germany, 2020. [CrossRef]

30. Boano, F.; Caruso, A.; Costamagna, E.; Ridolfi, L.; Fiore, S.; Demichelis, F.; Galvão, A.; Pisoeiro, J.; Rizzo, A.; Masi, F. A review of nature-based solutions for greywater treatment: Applications, hydraulic design, and environmental benefits. Sci. Total Environ. 2020, 711, 134731. [CrossRef]

31. Burkhardt, M.; Rohr, M.; Heisterkamp, I.; Gartiser, S. niederschlahswasser von kunststoffdachbahnen_auslaugung von stoffen und deren ökotoxizität für aquatische organismen. Korresp. Wasserwirtsch. 2020, 13, 418-424.

32. Bandow, N.; Gartiser, S.; Ilvonen, O.; Schoknecht, U. Evaluation of the impact of construction products on the environment by leaching of possibly hazardous substances. Environ. Sci. Eur. 2018, 30, 14. [CrossRef]

33. Rasul, M.G.; Arutla, L. Environmental impact assessment of green roofs using life cycle assessment. Energy Rep. 2020, 6, 503-508. [CrossRef]

34. Gromaire, M.C.; Bretaudeau, K.L.; Bret, C.M.; Caupos, E.; Seidl, M. Organic Micropollutants in Roof Runoff-A Study of the Emission/Retention Potential of Green Roofs. In Proceedings of the 13th International Conference on Urban Drainage, Kuching, Sarawak, 7-12 September 2014; p. 2516832.

35. Winters, N.L.; Graunke, K. Roofing Materials Assessment: Investigation of Toxic Chemicals in Roof Runoff; Washington State Department of Ecology Olympia: Olympia, WA, USA, 2014.

36. Gromaire, M.C.; Van De Voorde, A.; Lorgeoux, C.; Chebbo, G. Benzalkonium runoff from roofs treated with biocide products - In situ pilot-scale study. Water Res. 2015, 81, 279-287. [CrossRef]

37. EFRA. Frequently Asked Questions on Flame Retardants: How do They Work? EFRA: Brussels, Belgium, 2011.

38. Ghisari, M.; Bonefeld-Jorgensen, E.C. Effects of plasticizers and their mixtures on estrogen receptor and thyroid hormone functions. Toxicol. Lett. 2009, 189, 67-77. [CrossRef]

39. Togerö, Å. Leaching of Hazardous Substances from Additives and Admixtures in Concrete. Environ. Eng. Sci. 2006, 23, 102-117. [CrossRef]

40. Müller, A.; Österlund, H.; Nordqvist, K.; Marsalek, J.; Viklander, M. Building surface materials as sources of micropollutants in building runoff: A pilot study. Sci. Total Environ. 2019, 680, 190-197. [CrossRef] [PubMed]

41. Gerzhova, N.; Blanchet, P.; Dagenais, C.; Ménard, S.; Côté, J. Flammability Characteristics of Green Roofs. Buildings. 2020, 10, 126. [CrossRef]

42. Capolupo, M.; Sørensen, L.; Jayasena, K.D.R.; Booth, A.M.; Fabbri, E. Chemical composition and ecotoxicity of plastic and car tire rubber leachates to aquatic organisms. Water Res. 2020, 169, 115270. [CrossRef]

43. Morau, D.; Rabarison, T.; Rakotondramiarana, H. Life Cycle Analysis of Green Roof Implemented in a Global South Low-income Country. Br. J. Environ. Clim. Chang. 2017, 7, 43-55. [CrossRef]

44. Kotsiris, G.; Androutsopoulos, A.; Polychroni, E.; Souliotis, M.; Kavga, A. Carbon footprint of green roof installation on school buildings in Greek Mediterranean climatic region. Int. J. Sustain. Energy. 2019, 38, 866-883. [CrossRef]

45. Bianchini, F.; Hewage, K. How "green" are the green roofs? Lifecycle analysis of green roof materials. Build Environ. 2012, 48, 57-65. [CrossRef]

46. Manso, M.; Castro-Gomes, J.; Paulo, B.; Bentes, I.; Teixeira, C.A. Life cycle analysis of a new modular greening system. Sci. Total Environ. 2018, 627, 1146-1153. [CrossRef]

47. Koura, J.; Manneh, R.; Belarbi, R.; El Khoury, V.; El Bachawati, M. Comparative cradle to grave environmental life cycle assessment of traditional and extensive vegetative roofs: An application for the Lebanese context. Int. J. Life Cycle Assess. 2020, 25, 423-442. [CrossRef] 
48. Rider, C.V.; Janardhan, K.S.; Rao, D.; Morrison, J.P.; McPherson, C.A.; Harry, G.J. Evaluation of N-butylbenzenesulfonamide (NBBS) neurotoxicity in Sprague-Dawley male rats following 27-day oral exposure. Neurotoxicology. 2012, 33, $1528-1535$. [CrossRef]

49. Chenani, S.B.; Lehvävirta, S.; Häkkinen, T. Life cycle assessment of layers of green roofs. J. Clean. Prod. 2015, 90, 153-162. [CrossRef]

50. Maqbool, A.; Ahmas, B.S. Leaching of styrene and other aromatic compounds in drinking water from PS bottles. J. Environ. Sci. 2007, 19, 421-426.

51. Karczmarczyk, A.; Baryła, A.; Fronczyk, J.; Bus, A.; Mosiej, J. Phosphorus and Metals Leaching from Green Roof Substrates and Aggregates Used in Their Composition. Minerals. 2020, 10, 112. [CrossRef]

52. Alsup, S.E.; Ebbs, S.D.; Battaglia, L.L.; Retzlaff, W.A. Heavy metals in leachate from simulated green roof systems. Ecol. Eng. 2011, 37, 1709-1717. [CrossRef]

53. El Bachawati, M.; Manneh, R.; Belarbi, R.; Dandres, T.; Nassab, C.; El Zakhem, H. Cradle-to-gate Life Cycle Assessment of traditional gravel ballasted, white reflective, and vegetative roofs: A Lebanese case study: Cradle-to-gate Life Cycle Assessment of traditional gravel ballasted, white reflective, and vegetative roofs: A Lebanese case study. J. Clean. Prod. 2016, 137, 10.

54. Burkhardt, M.; Kupper, T.; Hean, S.; Haag, R.; Schmid, P.; Kohler, M.; Boller, M. Biocides used in building materials and their leaching behavior to sewer systems. Water Sci. Technol. 2007, 56, 63-67. [CrossRef]

55. Berndtsson, J.C.; Bengtsson, L.; Jinno, K. Runoff water quality from intensive and extensive vegetated roofs. Ecol. Eng. 2009, 35, 369-380. [CrossRef]

56. Speak, A.F.; Rothwell, J.J.; Lindley, S.J.; Smith, C.L. Metal and nutrient dynamics on an aged intensive green roof. Environ. Pollut. 2014, 184, 33-43. [CrossRef]

57. Hashemi, S.S.; Mahmud, H.B.; Ashraf, M.A. Performance of green roofs with respect to water quality and reduction of energy consumption in tropics: A review. Renew. Sustain. Energy Rev. 2015, 52, 669-679. [CrossRef]

58. Li, Y.; Babcock, R.W. Green roofs against pollution and climate change. A review. Agron. Sustain. Dev. 2014, 34, 695-705. [CrossRef]

59. Wang, H.; Qin, J.; Hu, Y. Are green roofs a source or sink of runoff pollutants? Ecol. Eng. 2017, 107, 65-70. [CrossRef]

60. Sainte, P. Contribution des Matériaux de Couverture à la Contamination Métallique des Eaux de Ruissellement. Ph.D. Thesis, Université Paris-Est, Paris, France, 2009.

61. Berndtsson, J.C.; Emilsson, T.; Bengtsson, L. The influence of extensive vegetated roofs on runoff water quality. Sci. Total Environ. 2006, 355, 48-63. [CrossRef]

62. Berndtsson, J.C. Green roof performance towards management of runoff water quantity and quality: A review. Ecol. Eng. 2010, 36, 351-360. [CrossRef]

63. Clark, S.E.; Lalor, M.M.; Pitt, R.; Field, R. Contribution of commonly used building materials to wet weather pollution. Proc. Water Environ. Fed. 2003, 12, 804-830. [CrossRef]

64. Gromaire, M.C.; GARNAUD, S.; Saad, M.; Chebbo, G. Contribution of Different Sources to THE Pollution of Wet Weather Flows in Combined Sewers. Water Res. 2001, 35, 521-533. [CrossRef]

65. Robert-Sainte, P.; Gromaire, M.C.; de Gouvello, B.; Saad, M.; Chebbo, G. Annual metallic flows in roof runoff from different materials: Test-bed scale in Paris conurbation. Environ. Sci. Technol. 2009, 43, 5612-5618. [CrossRef]

66. Clark, S.E.; Steele, K.A.; Spicher, J.; Siu, C.Y.; Lalor, M.M.; Pitt, R.; Kirby, J.T. Roofing Materials' Contributions to Storm-Water Runoff Pollution. J. Irrig. Drain Eng. 2008, 134, 638-645. [CrossRef]

67. McIntyre, J.K.; Winters, N.; Rozmyn, L.; Haskins, T.; Stark, J.D. Metals leaching from common residential and commercial roofing materials across four years of weathering and implications for environmental loading. Environ. Pollut. 2019, 255, 113262. [CrossRef]

68. Winters, N.; Granuke, K.; McCall, M. Roofing Materials Assessment: Investigation of Five Metals in Runoff from Roofing Materials. Water Environ. Res. 2015, 87, 835-848. [CrossRef]

69. Vijayaraghavan, K.; Joshi, U.M. Can green roof act as a sink for contaminants? A methodological study to evaluate runoff quality from green roofs. Environ. Pollut. 2014, 194, 121-129. [CrossRef]

70. USEPA. In National Recommended Water Quality Criteria-Correction; EPA 822-Z-99-001; US Environmental Protection Agency, Office of Water, S.W: Washington, DC, USA, 1999.

71. EC. Directive 2013/39/EU of the European Parliament and of the Council of 12 August 2013 amending Directives 2000/60/EC and 2008/105/EC as regards priority substances in the field of water policy. Off. J. Eur. Union. L 226/1-16. 2013.

72. Giacomello, E. Green Roofs, Facades, and Vegetative Systems. Chapter 3: Preliminary considerations: Safety Aspects in the Standards, 1st ed.; Butterworth-Heinemann_Elsevier: Amsterdam, The Netherlands, 2021; pp. 7-14. [CrossRef]

73. Elgizawy, E.M. The Effect of Green Facades in Landscape Ecology. Procedia. Environ. Sci. 2016, 34, 119-130. [CrossRef]

74. Bollmann, U.E.; Fernández-Calviño, D.; Brandt, K.K.; Storgaard, M.S.; Sanderson, H.; Bester, K. Biocide Runoff from Building Facades: Degradation Kinetics in Soil. Environ. Sci. Technol. 2017, 51, 3694-3702. [CrossRef] [PubMed]

75. Bollmann, U.E.; Tang, C.; Eriksson, E.; Jönsson, K.; Vollertsen, J.; Bester, K. Biocides in urban wastewater treatment plant influent at dry and wet weather: Concentrations, mass flows and possible sources. Water Res. 2014, 60, 64-74. [CrossRef] [PubMed]

76. Burkhardt, M.; Zuleeg, S.; Vonbank, R.; Bester, K.; Carmeliet, J.; Boller, M.; Wangler, T. Leaching of biocides from façades under natural weather conditions. Environ. Sci. Technol. 2012, 46, 5497-5503. [CrossRef] 
77. Wangler, T.P.; Zuleeg, S.; Vonbank, R.; Bester, K.; Boller, M.; Carmeliet, J.; Burkhardt, M. Laboratory scale studies of biocide leaching from façade coatings. Build. Env. 2012, 54, 168-173. [CrossRef]

78. Schoknecht, U.; Gruycheva, J.; Mathies, H.; Bergmann, H.; Burkhardt, M. Leaching of biocides used in façade coatings under laboratory test conditions. Environ. Sci. Technol. 2009, 43, 9321-9328. [CrossRef]

79. European Parliament and Council. REGULATION (EU) No 528/2012 concerning the making available on the market and use of biocidal products. Off. J. Eur. Union. 2012, 1-122. Available online: http:/ / data.europa.eu/eli/reg/2012/528/oj (accessed on 1 September 2021).

80. Paulus, W. Directory of Microbicides for the Protection of Materials: A Handbook; Springer Science \& Business Media: Berlin, Germany, 2005.

81. Jungnickel, C.; Stock, F.; Brandsch, T.; Ranke, J. Risk assessment of biocides in roof paint. Part 1: Experimental determination and modelling of biocide leaching from roof paint. Environ. Sci. Pollut. Res. Int. 2008, 15, 258-265. [CrossRef]

82. Burkhardt, M.; Zuleeg, S.; Eugster, J.; Boller, M.; Hean, S.; Haag, R.; Schmid, P.; Kohler, M. Mecoprop in Bitumenbahnen: Auswaschung von Mecoprop aus Bitumenbahnen und Vorkommen im Regenkanal. Eawag: Das Wasserforschungs-Institut des ETH-Bereichs Abteilung Siedlungswasserwirtschaft 2009. [CrossRef]

83. Bucheli, T.D.; Müller, S.R.; Voegelin, A.; Schwarzenbach, R.P. Bituminous Roof Sealing Membranes as Major Sources of the Herbicide (R, S )-Mecoprop in Roof Runoff Waters: Potential Contamination of Groundwater and Surface Waters. Environ. Sci. Technol. 1998, 32, 3465-3471. [CrossRef]

84. Pillonel, C.; Hitzfeld, B.; Burkhardt, M. Information über Mecoprop in Bitumen-Dachbahnen. In Eawag: Das WasserforschungsInstitut des ETH-Bereichs Abteilung Siedlungswasserwirtschaft; Eawag: Dübendorf, Switzerland, 2009; pp. 1-4.

85. Gerecke, A.C.; Scharer, M.; Singer, H.P.; Muller, S.R.; Schwarzenbach, R.P.; Sagesser, M.; Ochsenbein, U.; Popow, G. Sources of pesticides in surface waters in Switzerland: Pesticide load through waste water treatment plants-Current situation and reduction potential. Chemosphere. 2002, 48, 307-315. [CrossRef]

86. Lamprea, K.; Bressy, A.; Mirande-Bret, C.; Caupos, E.; Gromaire, M.C. Alkylphenol and bisphenol A contamination of urban runoff: An evaluation of the emission potentials of various construction materials and automotive supplies. Environ. Sci. Pollut. Res. Int. 2018, 25, 21887-21900. [CrossRef]

87. Björklund, K. Substance flow analyses of phthalates and nonylphenols in stormwater. Water Sci. Technol. 2010, 62, 1154-1160. [CrossRef]

88. Bressy, A.; Gromaire, M.-C.; Lorgeoux, C.; Chebbo, G. Alkylphenols in atmospheric depositions and urban runoff. Water Sci. Technol. 2011, 63, 671-679. [CrossRef]

89. Drozd, W. Problems and benefits of using green roofs in Poland. IOP Conf. Ser. Earth Environ. Sci. 2019, 214, 12076. [CrossRef]

90. Bayen, S.; Obbard, J.P.; Thomas, G.O. Chlorinated paraffins: A review of analysis and environmental occurrence. Environ. Int. 2006, 32, 915-929. [CrossRef]

91. Estill, C.F.; Slone, J.; Mayer, A.; Chen, I.C.; La Guardia, M.J. Worker exposure to flame retardants in manufacturing, construction and service industries. Environ. Int. 2020, 135, 105349. [CrossRef]

92. Cristale, J.; Hurtado, A.; Gómez-Canela, C.; Lacorte, S. Occurrence and sources of brominated and organophosphorus flame retardants in dust from different indoor environments in Barcelona, Spain. Environ. Res. 2016, 149, 66-76. [CrossRef]

93. Fohner, J.M. Nutrient Dynamics in Stormwater Runoff from Green Roofs with Varying Substrate. Ph.D. Thesis, University of Arkansas, Fayetteville, AR, USA, 2012.

94. Buffam, I.; Mitchell, M.E. Chapter 5: Nutrient Cycling in Green Roof Ecosystems. In Green Roof Ecosystems; Springer International Publishing: Cham, Switzerland, 2015; Volume 223, pp. 107-137. [CrossRef]

95. Aitkenhead-Peterson, J.A.; Dvorak, B.D.; Volder, A.; Stanley, N.C. Chemistry of growth medium and leachate from green roof systems in south-central Texas. Urban Ecosyst. 2011, 14, 17-33. [CrossRef]

96. Gregoire, B.G.; Clausen, J.C. Effect of a modular extensive green roof on stormwater runoff and water quality. Ecol. Eng. 2011, 37, 963-969. [CrossRef]

97. Fahimah, N.; Oginawati, K. Fate and spatial distribution of $\mathrm{Pb}, \mathrm{Cd}, \mathrm{Cu}$ and $\mathrm{Zn}$ in the water column and in the surface sediment of Indonesian Estuary (Citarum River Estuary). In E3S Web of Conferences; EDP Sciences: Les Ulis, France, 2020.

98. National Research Council. 4, Toxicity and Related Data on Selected Cadmium Compounds: Toxicologic Assessment of the Army's Zinc Cadmium Sulfide Dispersion Tests. 1997. Available online: https:/ / www.ncbi.nlm.nih.gov/books/NBK233504/ (accessed on 17 September 2021).

99. Masindi, V.; Muedi, K. Environmental Contamination by Heavy Metals. Heavy Metals. 2018, 10, 115-132.

100. NORMAN Network. NORMAN Substance Database. Available online: https://www.norman-network.com/nds/factsheets/ (accessed on 7 December 2020).

101. ECHA. Information on Chemicals. Available online: https://echa.europa.eu/de/information-on-chemicals (accessed on 1 September 2020).

102. Cuppett, J.D.; Duncan, S.E.; Dietrich, A.M. Evaluation of Copper Speciation and Water Quality Factors That Affect Aqueous Copper Tasting Response. Chem. Senses. 2006, 31, 689-697. [CrossRef] [PubMed]

103. Abadin, H.; Ashizawa, A.; Stevens, Y. Toxicological Profile for Lead. Atlanta (GA): Agency for Toxic Substances and Disease Registry (US). Table 4-2, Physical and Chemical Properties of Lead and Compounds. Available online: https:/ /www.ncbi.nlm. nih.gov/books/NBK158769/table/T15/ (accessed on 12 April 2021). 
104. IARC. Monographs on the Evaluation of Carcinogenic Risks to Humans, No. 49.) NICKEL AND NICKEL COMPOUNDS: Chromium, Nickel and Welding. Available online: https://www.ncbi.nlm.nih.gov/books/NBK519249/ (accessed on 22 April 2021).

105. ChemSpider. Search and Share Chemistry. Available online: http://www.chemspider.com/ (accessed on 7 December 2020).

106. National Pollutant Inventory. Zinc and Compunds. Available online: http://www.npi.gov.au/resource/zinc-and-compounds\#: $\sim\{\}$ :text=Zinc\%20is\%20insoluble\%20in\%20water,oxygen\%20to\%20give\%20zinc\%20oxide (accessed on 9 September 2020).

107. Agency for Toxic Substances and Disease Registry (ATSDR). Toxicological Profile for Zinc. 2005. Atlanta, Georgia, US. Available online: https: / /www.atsdr.cdc.gov / ToxProfiles/tp60.pdf (accessed on 4 May 2021).

108. University of Hertfordshire. PPDB: Pesticide Properties DataBase. Available online: https://sitem.herts.ac.uk/aeru/ppdb/en/ atoz.htm (accessed on 15 October 2020).

109. PubChem. Explore Chemistry. Available online: https://pubchem.ncbi.nlm.nih.gov/ (accessed on 9 December 2020).

110. US EPA. CompTox: Chemicals Dashboard. Available online: https://comptox.epa.gov/dashboard (accessed on 9 December 2020).

111. SciFinder. Substance Identifier. Available online: https:/ /scifinder.cas.org/scifinder/view/scifinder/scifinderExplore.jsf (accessed on 15 December 2020).

112. EU. European Union Risk Assessment Report-Bisphenol A. European Communities: Luxemburg, 2008.

113. Chen, C.; Guo, W.; Ngo, H.H. Pesticides in stormwater runoff-A mini review. Front. Environ. Sci. Eng. 2019, 13. [CrossRef]

114. Launay, M.A. Organic Micropollutants in Urban Wastewater Systems during Dry and Wet Weather: Occurrence, Spatio-temporal Distribution and Emissions to Surface Waters. Ph.D. Thesis, Universität Stuttgart, Stuttgart, Germany, 2017.

115. Margot, J. Micropollutant Removal from Municipal Wastewater from Conventional Treatments to Advanced Biological Processes. Swiss Federal Institute of Technology Lausanne: Lausanne, Switzerland, 2015.

116. Deffontis, S.; Breton, A.; Vialle, C.; Montréjaud-Vignoles, M.; Vignoles, C.; Sablayrolles, C. Impact of dry weather discharges on annual pollution from a separate storm sewer in Toulouse, France. Sci. Total Environ. 2013, 452-453, 394-403. [CrossRef]

117. Rippy, M.A.; Deletic, A.; Black, J.; Aryal, R.; Lampard, J.-L.; Tang, J.Y.-M.; McCarthy, D.; Kolotelo, P.; Sidhu, J.; Gernjak, W. Pesticide occurrence and spatio-temporal variability in urban run-off across Australia. Water Res. 2017, 115, 245-255. [CrossRef]

118. Huang, X.; Pedersen, T.; Fischer, M.; White, R.; Young, T.M. Herbicide runoff along highways. 1. Field observations. Environ. Sci. Technol. 2004, 38, 3263-3271. [CrossRef] [PubMed]

119. Vialle, C.; Sablayrolles, C.; Silvestre, J.; Monier, L.; Jacob, S.; Huau, M.-C.; Montrejaud-Vignoles, M. Pesticides in roof runoff: Study of a rural site and a suburban site. J. Environ. Manage. 2013, 120, 48-54. [CrossRef]

120. Gómez-Ramírez, P.; García-Fernández, A.J. Mecoprop. Encycl. Toxicol. 2014, 3, 176-179. [CrossRef]

121. Wang, S.; He, Q.; Ai, H.; Wang, Z.; Zhang, Q. Pollutant concentrations and pollution loads in stormwater runoff from different land uses in Chongqing. J. Environ. Sci. 2013, 25, 502-510. [CrossRef]

122. Nickel, J.P.; Fuchs, S. Micropollutant emissions from combined sewer overflows. Water Sci. Technol. 2019, 80, 2179-2190. [CrossRef] [PubMed]

123. Bressy, A.; Gromaire, M.-C.; Lorgeoux, C.; Saad, M.; Leroy, F.; Chebbo, G. Towards the determination of an optimal scale for stormwater quality management: Micropollutants in a small residential catchment. Water Res. 2012, 46, 6799-6810. [CrossRef] [PubMed]

124. Zgheib, S.; Moilleron, R.; Chebbo, G. Screening of priority pollutants in urban stormwater: Innovative methodology. Water Pollut. IX. 2008, 111, 235-244.

125. Zgheib, S.; Moilleron, R.; Chebbo, G. Priority pollutants in urban stormwater: Part 1-Case of separate storm sewers. Water Res. 2012, 46, 6683-6692. [CrossRef]

126. Launay, M.A.; Dittmer, U.; Steinmetz, H. Organic micropollutants discharged by combined sewer overflows-Characterisation of pollutant sources and stormwater-related processes. Water Res. 2016, 104, 82-92. [CrossRef] [PubMed]

127. Hollender, J.; Rothardt, J.; Radny, D.; Loos, M.; Epting, J.; Huggenberger, P.; Borer, P.; Singer, H. Comprehensive micropollutant screening using LC-HRMS/MS at three riverbank filtration sites to assess natural attenuation and potential implications for human health. Water. Res. X. 2018, 1, 100007. [CrossRef]

128. Schaffer, M.; Licha, T. A guideline for the identification of environmentally relevant, ionizable organic molecule species. Chemosphere. 2014, 103, 12-25. [CrossRef]

129. ECHA. Guidance on Information Requirements and Chemical Safety Assessment: Chapter R.11: PBT/vPvB Assessment; ED-01-17-294-ENN; European Chemicals Agency: Helsinki, Finland, 2017.

130. Von der Ohe, P.C.; Dulio, V. NORMAN Prioritisation Framework for Emerging Substances; Norman Association: Verneuil-en-Halatt, France, 2013; ISBN 978-2-9545254-0-2.

131. Wicke, D.; Matzinger, A. Relevanz Organischer Spurenstoffe im Regenwasserabfluss Berlins—Ogre; Kompetenzzentrum Wasser Berlin GmbH: Berlin, Germany, 2015.

132. Clara, M.; Gruber, G.; Humer, F.; Hofer, T.; Kretschmer, F.; Ertl, T.; Scheffknecht, C.; Weiß, S. Spurenstoffemissionen aus Siedlungsgebieten und von Verkehrsflächen. In Stuttgarter Berichte zur Siedlungswasserwirtschaft: Spurenstoffe im Regen-und Mischwasserabfluss; SCHTURM: Wien, Austria, 2014. Available online: https://www.bmnt.gv.at/service/publikationen/wasser/ Spurenstoffemissionen-aus-Siedlungsgebieten-und-von-Verkehrsflaechen.html (accessed on 7 December 2020). 
133. Gasperi, J.; Sebastian, C.; Ruban, V.; Delamain, M.; Percot, S.; Wiest, L.; Mirande, C.; Caupos, E.; Demare, D.; Kessoo, M.D.K.; et al. Micropollutants in urban stormwater: Occurrence, concentrations, and atmospheric contributions for a wide range of contaminants in three French catchments. Environ. Sci. Pollut. Res. 2014, 21, 5267-5281. [CrossRef]

134. Birch, H.; Mikkelsen, P.S.; Jensen, J.K.; Lützhøft, H.-C.H. Micropollutants in stormwater runoff and combined sewer overflow in the Copenhagen area, Denmark. Water Sci. Technol. 2011, 64, 485-493. [CrossRef] [PubMed]

135. Clara, M.; Gruber, G.; Hohenblum, P.; Hofer, T.; Kittlaus, S.; Lenz, K.; Liebmann, B.; Liedermann, M.; Maier, R.; Mallow, O.; et al. TEMPEST: Erfassung von Emissionen Ausgewählter Spurenstoffe aus Kanalsystemen, Handlungsoptionen zu Deren Minderung und Opimierung einer Alternativen Nachweismethode für Kunststoffpartikel in Wasserproben; Institute of Urban Water Management and Landscape Water Engineering: Wien, Austria, 2020.

136. EEA. Simulated Land Average Maximum Number of Consecutive Dry Days for Different European Regions (1860-2100). Available online: https: / / www.eea.europa.eu/data-and-maps/figures/simulated-land-average-maximum-number-of-consecutive-drydays-for-different-european-regions-1860-2100 (accessed on 17 June 2021).

137. Council of the European Communities. Directive 2000/60/Ec of the European Parliament and of The Council establishing a Framework for Community Action in the Field of Water Policy. Off. J. Eur. Communities. 2000, 327, 1-72.

138. More, S.J.; Bampidis, V.; Benford, D.; Bennekou, S.H.; Bragard, C.; Halldorsson, T.I.; Hernández-Jerez, A.F.; Koutsoumanis, K.; Naegeli, H.; Schlatter, J.R.; et al. Guidance on harmonised methodologies for human health, animal health and ecological risk assessment of combined exposure to multiple chemicals. EFSA J. 2019, 17, e05634. [CrossRef] [PubMed]

139. Zessner, M.; Kroiss, H.; Gabriel, O. Präzisierung von Qualitätszielen im Falle einer Anwendung bei der Einleitung aus Punktquellen im Auftrag von Bundesministerium für Land- und Forstwirtschaft, Umwelt und Wasserwirtschaft; Institut für Wassergüte und Abfallwirtschaft, Technische Universität Wien: Vienna, Austria, 2004.

140. ECHA. Guidance for the Identification of Endocrine Disruptors. Available online: https://echa.europa.eu/hot-topics/endocrinedisruptors (accessed on 30 August 2021).

141. Toshovski, S.; Kaiser, M.; Fuchs, S.; Sacher, F.; Thoma, A.; Kümmel, V.; Lambert, B. Prioritäre Stoffe in Kommunalen Kläranlagen: Ein Deutschlandweit Harmonisiertes Vorgehen No. 173, Dessau-Roßlau. 2020. Available online: https:/ /www.umweltbundesamt. de/publikationen/prioritaere-stoffe-in-kommunalen-klaeranlagen (accessed on 12 October 2020).

142. Boller, M. Nachhaltige Regenwasserentsorgung auf dem Weg in die Praxis. EAWAG News. 2003, 57, $25-28$.

143. Göbel, P.; Dierkes, C.; Coldewey, W. Storm water runoff concentration matrix for urban areas. J. Contam. Hydrol. 2007, 91, 26-42. [CrossRef]

144. Hürlimann, J. Auswirkungen von Straßenabwasser aus Oberflächengewässer. GWA. 2011, 91, 793-801.

145. Fuerhacker, M.; Haile, T.M.; Monai, B.; Mentler, A. Performance of a filtration system equipped with filter media for parking lot runoff treatment. Desalination. 2011, 275, 118-125. [CrossRef]

146. Fürhacker, M.; Haile, T.B.; Schärfinger, B.; Kammerer, G.; Allabashi, R.; Magnat, S.; Lins, A. Entwicklung von Methoden zur Prüfung der Eignung von Substraten für die Oberflächenwasserbehandlung von Dach- und Verkehrsflächen; Grant agreement GZ B100121; Bundesministerium für Land- und Forstwirtschaf: Vienna, Austria, 2013.

147. Zgheib, S.; Moilleron, R.; Saad, M.; Chebbo, G. Partition of pollution between dissolved and particulate phases: What about emerging substances in urban stormwater catchments? Water Res. 2011, 45, 913-925. [CrossRef] [PubMed]

148. Kasting, U. Reinigungsleistung von Zentralen Anlagen zur Behandlung von Abflüssen Stark Befahrener Straßen; Technische Universität Kaiserslautern: Kaiserslautern, Germany, 2002.

149. Burkhardt, M.; Zuleeg, S.; Vonbank, R.; Schmid, P.; Hean, S.; Lamani, X.; Bester, K.; Boller, M. Leaching of additives from construction materials to urban storm water runoff. Water Sci. Technol. 2011, 63, 1974-1982. [CrossRef]

150. Bollmann, U.E.; Vollertsen, J.; Carmeliet, J.; Bester, K. Dynamics of biocide emissions from buildings in a suburban stormwater catchment - Concentrations, mass loads and emission processes. Water Res. 2014, 56, 66-76. [CrossRef]

151. Bollmann, U.E.; Minelgaite, G.; Schlüsener, M.; Ternes, T.A.; Vollertsen, J.; Bester, K. Photodegradation of octylisothiazolinone and semi-field emissions from facade coatings. Sci. Rep. 2017, 7, 41501. [CrossRef]

152. Gasperi, J.; Garnaud, S.; Rocher, V.; Moilleron, R. Priority pollutants in wastewater and combined sewer overflow. Sci. Total Env. 2008, 407, 263-272. [CrossRef]

153. Fuchs, S.; Snezhina, T.; Kaiser, M.; Sacher, F.; Thoma, A. Belastung der Umwelt mit Bioziden Realistischer Erfassen - Schwerpunkt Einträge über Kläranlagen; UBA-Texte 169/2020, Dessau-Roßlau. 2020. Available online: https: / www.umweltbundesamt.de/ sites/default/files/medien/479/publikationen/texte_169-2020_belastung_der_umwelt_mit_bioziden_realistischer_erfassen_ -_schwerpunkt_eintraege_ueber_klaeranlagen.pdf (accessed on 9 February 2021).

154. Bollmann, U.E.; Minelgaite, G.; Schlüsener, M.; Ternes, T.; Vollertsen, J.; Bester, K. Leaching of Terbutryn and Its Photodegradation Products from Artificial Walls under Natural Weather Conditions. Environ. Sci. Technol. 2016, 50, 4289-4295. [CrossRef] [PubMed]

155. Couderc, M.; Poirier, L.; Zalouk-Vergnoux, A.; Kamari, A.; Blanchet-Letrouvé, I.; Marchand, P.; Vénisseau, A.; Veyrand, B.; Mouneyrac, C.; Le Bizec, B. Occurrence of POPs and other persistent organic contaminants in the European eel (Anguilla anguilla) from the Loire estuary, France. Sci. Total Environ. 2015, 505, 199-215. [CrossRef]

156. Masoner, J.R.; Kolpin, D.W.; Cozzarelli, I.M.; Barber, L.B.; Burden, D.S.; Foreman, W.T.; Forshay, K.J.; Furlong, E.T.; Groves, J.F.; Hladik, M.L.; et al. Urban Stormwater: An Overlooked Pathway of Extensive Mixed Contaminants to Surface and Groundwaters in the United States. Environ. Sci. Technol. 2019, 53, 10070-10081. [CrossRef] [PubMed] 
157. Cladière, M.; Gasperi, J.; Lorgeoux, C.; Tassin, B. Discharges of endocrine disrupting chemicals by combined sewer overflows into receiving water: Case-study of the Paris conurbation. In Proceedings of the 11th Edition of the World Wide Workshop for Young Environmental Scientists (WWW-YES-2011)—Urban Waters: Resource or Risks? Arcueil, France, 6-10 June 2011.

158. Boyd, G.R.; Grimm, D.A.; Palmeri, J.M.; Zhang, S. Pharmaceuticals and personal care products (PPCPs) and endocrine disrupting chemicals (EDCs) in stormwater canals and Bayou St. John in New Orleans, Louisiana, USA. Sci. Total Environ. 2004, 333, 137-148. [CrossRef]

159. Tran, N.H.; Reinhard, M.; Khan, E.; Chen, H.; Nguyen, V.H.; Li, Y.; Goh, S.G.; Nguyen, Q.B.; Saeidi, N.; Gin, K.N. Emerging contaminants in wastewater, stormwater runoff, and surface water: Application as chemical markers for diffuse sources. Sci. Total Environ. 2019, 676, 252-267. [CrossRef] [PubMed]

160. Barriuso, F.; Urbano, B. Green Roofs and Walls Design Intended to Mitigate Climate Change in Urban Areas across All Continents. Sustainability. 2021, 13, 2245. [CrossRef]

161. Köhler, M.; Schmidt, M. Study of Extensive Green Roofs in Berlin: Part 3 Retention of Contaminatnts; Köhler and Schmidt: Waldrohrbach, Germany, 2003.

162. Long, B.; Clark, S.E.; Baker, K.H.; Berghage, R. Green Roof Media Selection for the Minimization of Pollutant Loadings in Roof Runoff. Proc. Water Environ. Fed. 2006, 2006, 5528-5548. [CrossRef]

163. Silva, V.; Silva, C.; Soares, P.; Garrido, E.M.; Borges, F.; Garrido, J. Isothiazolinone Biocides: Chemistry, Biological, and Toxicity Profiles. Molecules 2020, 25, 991. [CrossRef] [PubMed]

164. Jane Clark, M.; Zheng, Y. Plant Nutrition Requirements for an Installed Sedum-Vegetated Green Roof Module System: Effects of Fertilizer Rate and Type on Plant Growth and Leachate Nutrient Content. HortScience 2013, 48, 1173-1180. [CrossRef]

165. Flanagan, K.; Branchu, P.; Boudahmane, L.; Caupos, E.; Demare, D.; Deshayes, S.; Dubois, P.; Meffray, L.; Partibane, C.; Saad, M.; et al. Field performance of two biofiltration systems treating micropollutants from road runoff. Water Res. 2018, 145, 562-578. [CrossRef]

166. Austrian Standards Institute. ÖNORM B 2506-3: Regenwasser-Sickeranlagen Für Abläufe von Dachflüchen und Befestigten Flächen; Austrian Standards Institute: Vienna, Austria, 2018.

167. Al-Anbari, R.H.; Wootton, K.P.; Durmanic, S.; Deletic, A.; Fletcher, T.D. Evaluation of media for the adsorption of stormwater pollutants. In Proceedings of the 11th International Conference on Urban Drainage, Edinburgh, Scotland, 31 August-5 September 2008.

168. Cheng, Y.; Fassman-Beck, E. The effect of zeolite amendments on nitrogen leaching from extensive sedum green roofs. NOVATECH 2019, 1-4. Available online: http:/ / www.novatech.graie.org/documents/auteurs/3D74-202CHE.pdf (accessed on 17 May 2021).

169. Kuoppamäki, K.; Lehvävirta, S. Mitigating nutrient leaching from green roofs with biochar. Landsc. Urban Plan. 2016, 152, 39-48. [CrossRef]

170. Qianqian, Z.; Liping, M.; Huiwei, W.; Long, W. Analysis of the effect of green roof substrate amended with biochar on water quality and quantity of rainfall runoff. Environ. Monit. Assess. 2019, 191, 304. [CrossRef] [PubMed]

171. Spahr, S.; Teixidó, M.; Sedlak, D.L.; Luthy, R.G. Hydrophilic trace organic contaminants in urban stormwater: Occurrence, toxicological relevance, and the need to enhance green stormwater infrastructure. Environ. Sci. Water Res. Technol. 2020, 6, 15-44. [CrossRef]

172. Bester, K.; Banzhaf, S.; Burkhardt, M.; Janzen, N.; Niederstrasser, B.; Scheytt, T. Activated soil filters for removal of biocides from contaminated run-off and waste-waters. Chemosphere. 2011, 85, 1233-1240. [CrossRef] [PubMed]

173. Braswell, A.S.; Anderson, A.R.; Hunt, W.F. Hydrologic and Water Quality Evaluation of a Permeable Pavement and Biofiltration Device in Series. Water. 2018, 10, 33. [CrossRef]

174. Ashoori, N.; Teixido, M.; Spahr, S.; LeFevre, G.H.; Sedlak, D.L.; Luthy, R.G. Evaluation of pilot-scale biochar-amended woodchip bioreactors to remove nitrate, metals, and trace organic contaminants from urban stormwater runoff. Water Res. 2019, 154, 1-11. [CrossRef] [PubMed]

175. Williams, T.; Jacobson, A. Environmental Fate of Isothiazolone Biocides. In CORROSION 99; OnePetro: San Antonio, TX, USA, 1999.

176. Zhang, D.; Gersberg, R.M.; Ng, W.J.; Tan, S.K. Conventional and decentralized urban stormwater management: A comparison through case studies of Singapore and Berlin, Germany. Urban Water J. 2017, 14, 113-124. [CrossRef] 